\title{
Predicting Failure Modes of Resistance Spot Welds from the Chemical Composition of Materials
}

\author{
소재의 화학 성분에 따른 저항 점 용접부의 파단 모드 예측 \\ Heewon Cho*, Sangwoo Nam**,***, Minjung Kang***, Munjin Kang*** \\ and Young-Min $\mathrm{Kim}^{* * *, \dagger}$ \\ *Pack. DFM verification, LG Chem, Daejeon, 34122, Korea \\ **Department of Materials Science and Engineering, Seoul National University, Seoul, 08826, Korea \\ ***Advanced Functional Technology R\&D Department, Korea Institute of Industrial Technology, \\ Incheon, 21999, Korea
}

†Corresponding author : ymkim77@kitech.re.kr

(Received July 16, 2020 ; Revised August 3, 2020 ; Accepted August 10, 2020)

\begin{abstract}
The failure mode of resistance spot welds on steel sheets was predicted according to the chemical composition of the materials. Resistance spot welding was performed on various steels sheets ranging from 440 to $1180 \mathrm{MPa}$ grade steel. Tensile strength tests were performed, and the size and hardness of the nuggets were measured to analyze the mechanical properties of the welds. The hardness values of the fusion zone and heat affected zone were determined on the basis of the chemical composition of the materials. The interfacial and pull-out-failure-generated loads were calculated and compared to predict the failure mode of the welds. The failure mode prediction results demonstrated a trend analogous to the experimental results.
\end{abstract}

Key Words : Resistance spot welding, Prediction, Hardness, Failure mode, Carbon equivalent, Advanced high strength steel

\section{Introduction}

Resistance spot welding is a process that offers high productivity owing to its short processing time and is used in more than $70 \%$ of car bodies ${ }^{1-3)}$. To assess the weld quality of resistance spot welds, performance measures such as maximum load, failure mode, and nugget diameter are inspected. While destructive testing is essential to evaluate these parameters, performing destructive testing on automotive body structures is not only difficult but also costly and time-consuming.

In recent years, there has been an increasing demand for environmental regulations on reducing exhaust gas emissions. In the automotive industry, reduction of exhaust gas emissions and increase in fuel efficiency can be achieved by reducing the weight of vehicles ${ }^{4}$. Modern automotive bodies use materials such as aluminum, high strength steel, and carbon-fiber reinforced plastics $(\mathrm{CFRP})^{5}$. High strength steel, which exhibits high strength relative to its small thickness, has recently been widely applied to the automotive industry due to the demand for stability and weight reduction of vehicles ${ }^{6}$. However, problems such as poor weldability arise in high strength steel as various alloying elements are added to the material to provide enhanced mechanical properties ${ }^{7,8)}$. Unlike conventional steel, high-strength steel has a narrow range of welding conditions due to expulsion that occurs even at relatively low currents. Moreover, even when the nugget size becomes sufficiently large, interfacial failure occurs more frequently than pull out failure ${ }^{9-11)}$.

Studies investigating the mechanical properties of newly developed steel as well as low-strength steel have been carried out continuously. Zhao et al. conducted tensile shear tests on resistance spot-welded joints of 
DP600, examined the effect of electrode force on the tensile shear load and failure energy absorption, and investigated the failure mode and microstructure ${ }^{12)}$. The study concluded that the weld nugget size was affected by the failure mode and failure energy. Zhang et al. performed resistance spot welding on DP780 and DP600 and investigated the microstructure and mechanical properties of single-lap joints between the two materials ${ }^{13)}$. The failure mode was shown to be primarily dependent on the nugget size, and a critical nugget diameter associated with the transition from interfacial failure to pull out failure was identified. Nikoosohbat et al. carried out resistance spot welding on DP980, a material with higher strength compared to that of materials used in the aforementioned studies, and investigated the mechanical properties, microstructure, and failure behavior $^{14)}$. The study reported that, in pull out failure mode, failure generally occurred at the interface of the base material (BM) and the heat-affected zone (HAZ) where softening took place. Furthermore, the study suggested that a new weld quality assurance was necessary for high strength steel, as the weld size recommendation of $4 \sqrt{ } \mathrm{t}$ was not sufficient to ensure the pull out failure for DP980. Many other studies have been conducted on high strength steels that exhibit higher sensitivity to interfacial failure than pull out failure ${ }^{15-17)}$.

Research on predicting the weld quality of resistance spot welds without involving destructive testing has also continued. Yang et al. developed a computational model to predict the performance of DP590 resistance spot welds ${ }^{18)}$. This model, which consisted of a welding process model and a local model, predicted the residual stress and plastic deformation of the spot welds. Radakovic and Tumuluru conducted resistance spot welding on DP590, DP780, and TRIP780, and finite element modeling (FEM) was performed to predict the failure modes ${ }^{19)}$. The plastic strain and predicted failure loads associated with the failure modes were calculated based on the analysis, and the equations derived from FEM showed that the force required to result in pull out failure is proportional to not only tensile strength but also the steel thickness and nugget diameter. In addition to predicting the weld quality of resistance spot welds using analysis modeling software, the tensile shear strength, nugget diameter, failure mode, and expulsion occurrence were predicted using the external image of the spot weld and a convolution neural network (CNN), which is one of the deep learning algorithms ${ }^{20)}$. However, analysis predicted through computer simulations and methods using artificial intelligence require long computational times. Moreover, predictive methods using artificial intelligence require large volumes of input data, such that a full factorial experiment must be preceded. The maximum strength of the material used in the work described earlier was $980 \mathrm{MPa}$, and only one type of material was studied in general. Furthermore, the model for weld quality prediction was also performed on one type of material or did not include materials ranging from low strength steel to high strength steel.

In this work, resistance spot welding was conducted on materials of varying strength from low strength steel to advanced high strength steel to investigate the mechanical properties of spot welds. In addition, the nugget size and hardness of spot welds were predicted by using the chemical composition of materials to evaluate the weld quality without destroying the weld joints. The calculated values were subsequently used to predict the failure modes, which were compared to actual failure modes.

\section{Materials and experimental methods}

\subsection{Materials}

In this study, resistance spot welding was conducted on $440,590,780,980$, and $1180 \mathrm{MPa}$-grade steels with a thickness of $1 \mathrm{~mm}$. The steel grade was used to denote each material, and the chemical composition is listed in Table 1.

\subsection{Experimental methods}

A medium frequency direct current (MFDC) resist-

Table 1 Chemical composition (wt. \%) of the material used in this study

\begin{tabular}{|c|c|c|c|c|c|c|c|c|c|c|}
\hline \multirow{2}{*}{$\begin{array}{l}\text { Steel } \\
\text { grade }\end{array}$} & \multicolumn{10}{|c|}{ Chemical composition } \\
\hline & $\mathrm{C}$ & $\mathrm{Si}$ & $\mathrm{Mn}$ & $\mathrm{Ni}$ & $\mathrm{Cr}$ & Mo & $\mathrm{Cu}$ & $\mathrm{V}$ & $\mathrm{Nb}$ & B \\
\hline 440 & 0.088 & 0.019 & 1.480 & 0.015 & 0.031 & 0.007 & 0.013 & 0.003 & 0.004 & $<0.001$ \\
\hline 590 & 0.079 & 1.350 & 1.770 & 0.013 & 0.028 & 0.006 & 0.012 & 0.004 & 0.006 & $<0.001$ \\
\hline 780 & 0.067 & 1.120 & 2.290 & 0.013 & 0.031 & 0.020 & 0.019 & 0.003 & 0.023 & $<0.001$ \\
\hline 980 & 0.071 & 0.470 & 2.330 & 0.023 & 0.890 & 0.120 & 0.025 & 0.006 & 0.053 & 0.003 \\
\hline 1180 & 0.130 & 0.130 & 2.620 & 0.031 & 0.680 & 0.008 & 0.018 & 0.006 & 0.030 & 0.002 \\
\hline
\end{tabular}




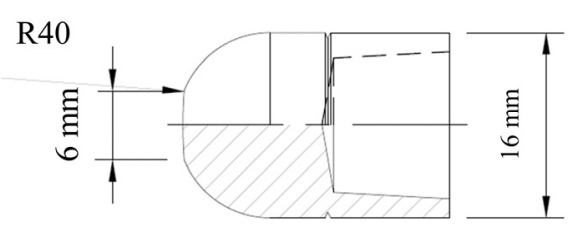

(a)

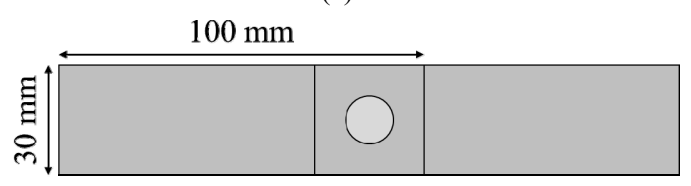

(b)

Fig. 1 Schematic images of (a) electrode shape and (b) specimen size

Table 2 Resistance spot welding conditions used in this study

\begin{tabular}{|c|c|c|c|c|}
\hline $\begin{array}{c}\text { Electrode face } \\
\text { diameter }\end{array}$ & $\begin{array}{c}\text { Electrode } \\
\text { force }\end{array}$ & $\begin{array}{c}\text { Welding } \\
\text { current }\end{array}$ & $\begin{array}{c}\text { Welding } \\
\text { time }\end{array}$ & $\begin{array}{c}\text { Holding } \\
\text { time }\end{array}$ \\
\hline $6 \mathrm{~mm}$ & $3 \mathrm{kN}$ & $4-12 \mathrm{kA}$ & $333 \mathrm{~ms}$ & $167 \mathrm{~ms}$ \\
\hline
\end{tabular}

ance spot welder was used as the welding power source, and a schematic of the shape of the electrode used in this work is displayed in Fig. 1(a). A dome-shaped welding electrode was used, and the electrode tip diameter and tip radius were $6 \mathrm{~mm}$ and $40 \mathrm{~mm}$, respectively (Fig. 1(a)). Welding current ranging from $4 \mathrm{kA}$ to $12 \mathrm{kA}$ was used, while the electrode force and welding time were respectively fixed at $3 \mathrm{kN}$ and $333 \mathrm{~ms}$ (Table 2). To evaluate the welding quality of the joint upon resistance spot welding, the tensile shear strength, nugget size, and hardness were measured. Tensile shear testing was conducted using AG-300kNXPlus (Shimazu, Japan) at a strain rate of $10 \mathrm{~mm} / \mathrm{min}$. The tensile test specimen was prepared in accordance with KS B 0851 (Specimen Dimensions and Procedure for Shear Testing Resistance Spot and Embossed Projection Welded Joints) by overlapping $100 \mathrm{~mm}$-long and $30 \mathrm{~mm}$-wide materials by 30 $\mathrm{mm}$ and performing spot welding the joint (Fig. 1(b)). Hardness measurements were conducted with HM-101 (Mitutoyo, Japan) using an indentation load of $200 \mathrm{~g}$. The weld nugget size was measured using an optical microscope after cross-sectioning and etching the center of the nugget. Failure modes were determined from the results of the tensile shear tests.

\section{Results and discussion}

\subsection{Mechanical properties of resistance spot welds}

Fig. 2 and 3 respectively show the tensile shear strength and nugget size with respect to the change in welding

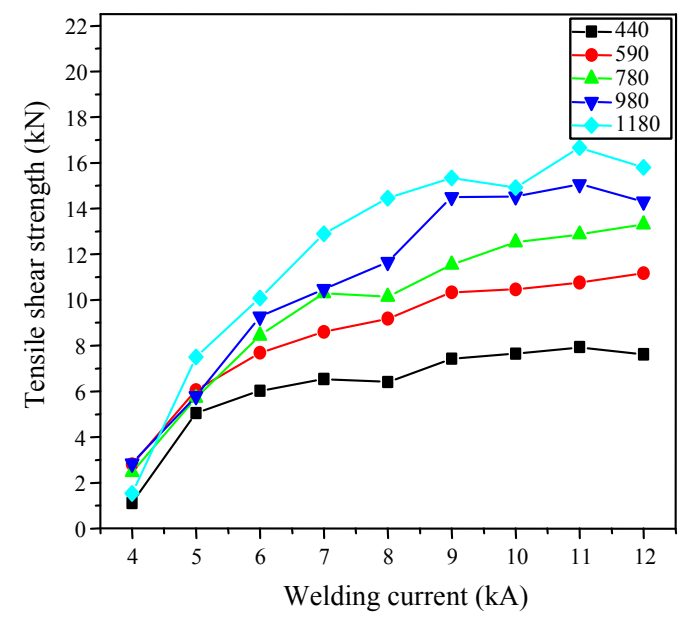

Fig. 2 Tensile shear strength according to welding current

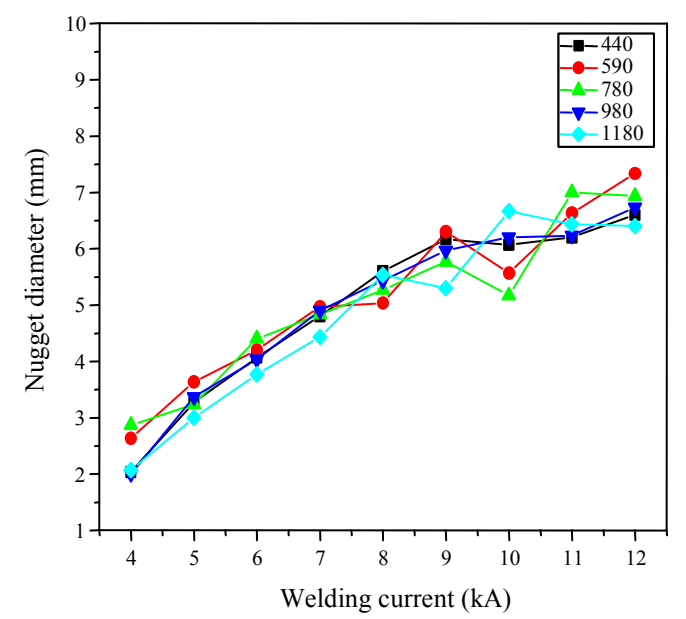

Fig. 3 Nugget diameter according to welding current

current. Both tensile shear strength and nugget size exhibited increasing trends with increasing current, and the tensile shear strength generally leveled off at currents higher than $9 \mathrm{kA}$. Except in the $1180 \mathrm{MPa}$-grade steel, the nugget size also continued to increase up to a current of $9 \mathrm{kA}$, beyond which the nugget size showed a small increase or approached a steady value. The correlation between nugget size and tensile shear strength is presented in Fig. 4, which demonstrates that the slopes are different in all steel grades, but the tensile shear strength increases linearly as the nugget size increases.

Tensile shear tests showed that failure modes of interfacial failure (IF) and pull out failure (PF) occurred, and the failure modes of the spot welds of each material with respect to current are summarized in Table 3. PF occurred at a lower current range of $5 \mathrm{kA}$ in the $440 \mathrm{MPa}-$ grade steel, at $6 \mathrm{kA}$ in 590, 780, and $1180 \mathrm{MPa}$-grade steels, and $7 \mathrm{kA}$ at the $980 \mathrm{MPa}$-grade steel.

Fig. 5 shows the hardness profile of each steel grade. To accurately capture the representative hardness value 


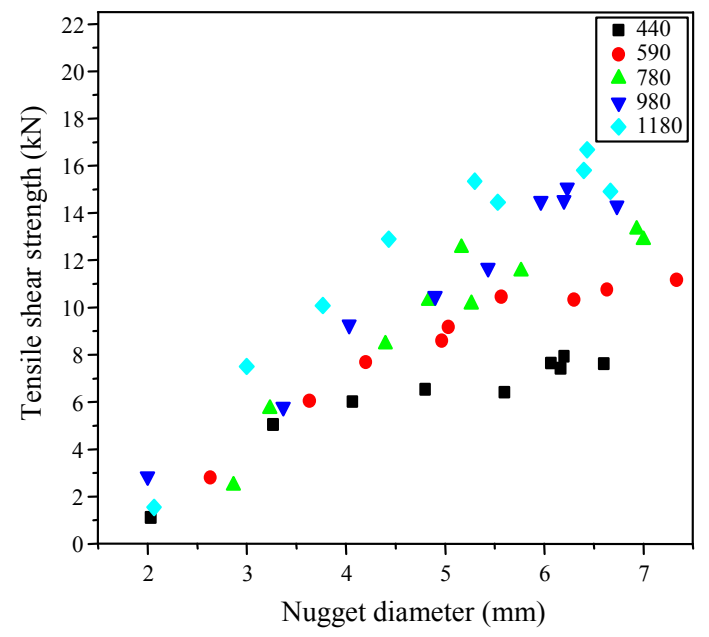

Fig. 4 Tensile shear strength according to nugget diameter

of the heat-affected zone (HAZ), the average hardness of the HAZ was used when HAZ softening did not occur, while the minimum hardness was used when HAZ softening was present in the HAZ. The hardness values of the base material (BM) of each steel grade were $157.1,212.2,263.8,326.2$, and $395.3 \mathrm{HV}$, and the hardness increased as the BM strength increased. The hardness values of each steel grade at the fusion zone (FZ) were 407.4, 424.2, 414.2, 421.9, and 451.9 HV, where the hardness was the lowest in the $440 \mathrm{MPa}$-grade steel, highest in $1180 \mathrm{MPa}$-grade steel, and similar across 590, 780, and $980 \mathrm{MPa}$-grade steels. HAZ softening, in which the hardness of the HAZ is lower than that of the $\mathrm{BM}$, occurred in 780, 980, and $1180 \mathrm{MPa}$-grade steels, where the lowest hardness values were 254.8, 316.2, and $311.6 \mathrm{HV}$, respectively. The difference between the hardness of the BM and the minimum hardness of the HAZ in 780, 980, and $1180 \mathrm{MPa-grade}$ steels was 9, 10 , and $84 \mathrm{HV}$, respectively, which was the greatest in the $1180 \mathrm{MPa}$-steel.

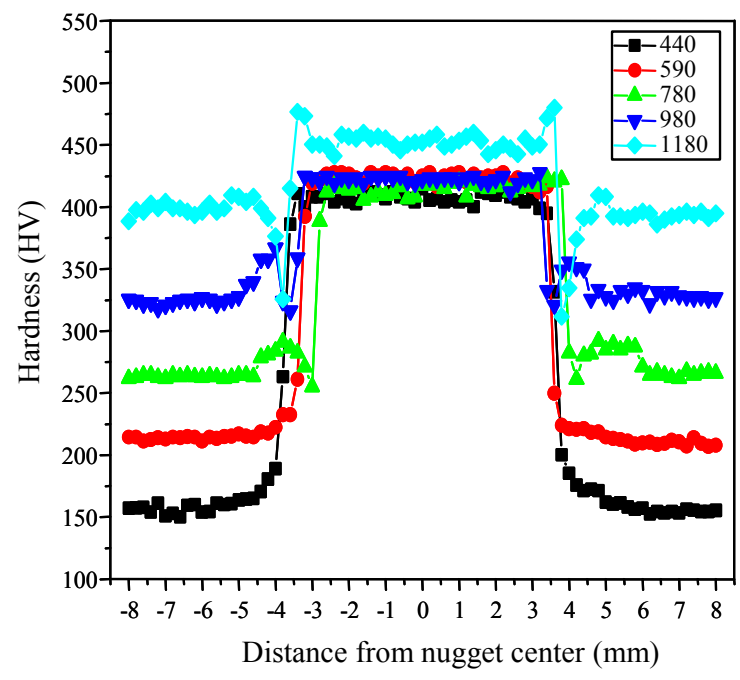

\begin{tabular}{|c|c|c|c|c|c|c|}
\hline \multicolumn{2}{|c|}{ Steel grade $(\mathrm{MPa})$} & 440 & 590 & 780 & 980 & 1180 \\
\hline \multirow{3}{*}{$\begin{array}{c}\text { Hardness } \\
(\mathrm{HV})\end{array}$} & $\mathrm{BM}$ & 157.1 & 212.2 & 263.8 & 326.2 & 395.3 \\
\cline { 2 - 7 } & $\mathrm{FZ}$ & 407.4 & 424.2 & 414.2 & 421.9 & 451.9 \\
\cline { 2 - 7 } & $\mathrm{HAZ}$ & 170.4 & 217.4 & 254.8 & 316.2 & 311.6 \\
\hline
\end{tabular}

Fig. 5 Hardness profile of welded specimens with different steel grade

\subsection{Microstructure characteristics of resistance spot welds}

Fig. 6 shows the microstructure of resistance spot welds. The microstructure of resistance spot welds can be divided into three types: BM, HAZ, and FZ. Here, the HAZ can be subdivided into three zones based on the distance between the HAZ and FZ: upper critical HAZ (UCHAZ) that is closest to the FZ, sub critical HAZ (SCHAZ) that is closest to the BM, and inter critical HAZ (ICHAZ) that is between the UCHAZ and SCHAZ. HAZ and FZ from the $440 \mathrm{MPa}$-grade steel are presented as representative images of the micro-

Table 3 Failure mode of welds with steel grade according to welding current

\begin{tabular}{|c|c|c|c|c|c|}
\hline Steel grade $(\mathrm{MPa})$ & \multirow{2}{*}{440} & \multirow{2}{*}{590} & \multirow{2}{*}{780} & \multirow{2}{*}{980} & \multirow{2}{*}{1180} \\
\hline Current & & & & & \\
\hline $4 \mathrm{kA}$ & IF & IF & IF & IF & IF \\
\hline $5 \mathrm{kA}$ & $\mathrm{PF}$ & IF & IF & IF & IF \\
\hline $6 \mathrm{kA}$ & $\mathrm{PF}$ & $\mathrm{PF}$ & $\mathrm{PF}$ & IF & $\mathrm{PF}$ \\
\hline $7 \mathrm{kA}$ & $\mathrm{PF}$ & $\mathrm{PF}$ & $\mathrm{PF}$ & $\mathrm{PF}$ & $\mathrm{PF}$ \\
\hline $8 \mathrm{kA}$ & $\mathrm{PF}$ & $\mathrm{PF}$ & $\mathrm{PF}$ & $\mathrm{PF}$ & $\mathrm{PF}$ \\
\hline $9 \mathrm{kA}$ & PF & $\mathrm{PF}$ & $\mathrm{PF}$ & $\mathrm{PF}$ & $\mathrm{PF}$ \\
\hline $10 \mathrm{kA}$ & $\mathrm{PF}$ & $\mathrm{PF}$ & $\mathrm{PF}$ & $\mathrm{PF}$ & $\mathrm{PF}$ \\
\hline $11 \mathrm{kA}$ & $\mathrm{PF}$ & $\mathrm{PF}$ & $\mathrm{PF}$ & $\mathrm{PF}$ & $\mathrm{PF}$ \\
\hline $12 \mathrm{kA}$ & PF & PF & PF & PF & $\mathrm{PF}$ \\
\hline
\end{tabular}




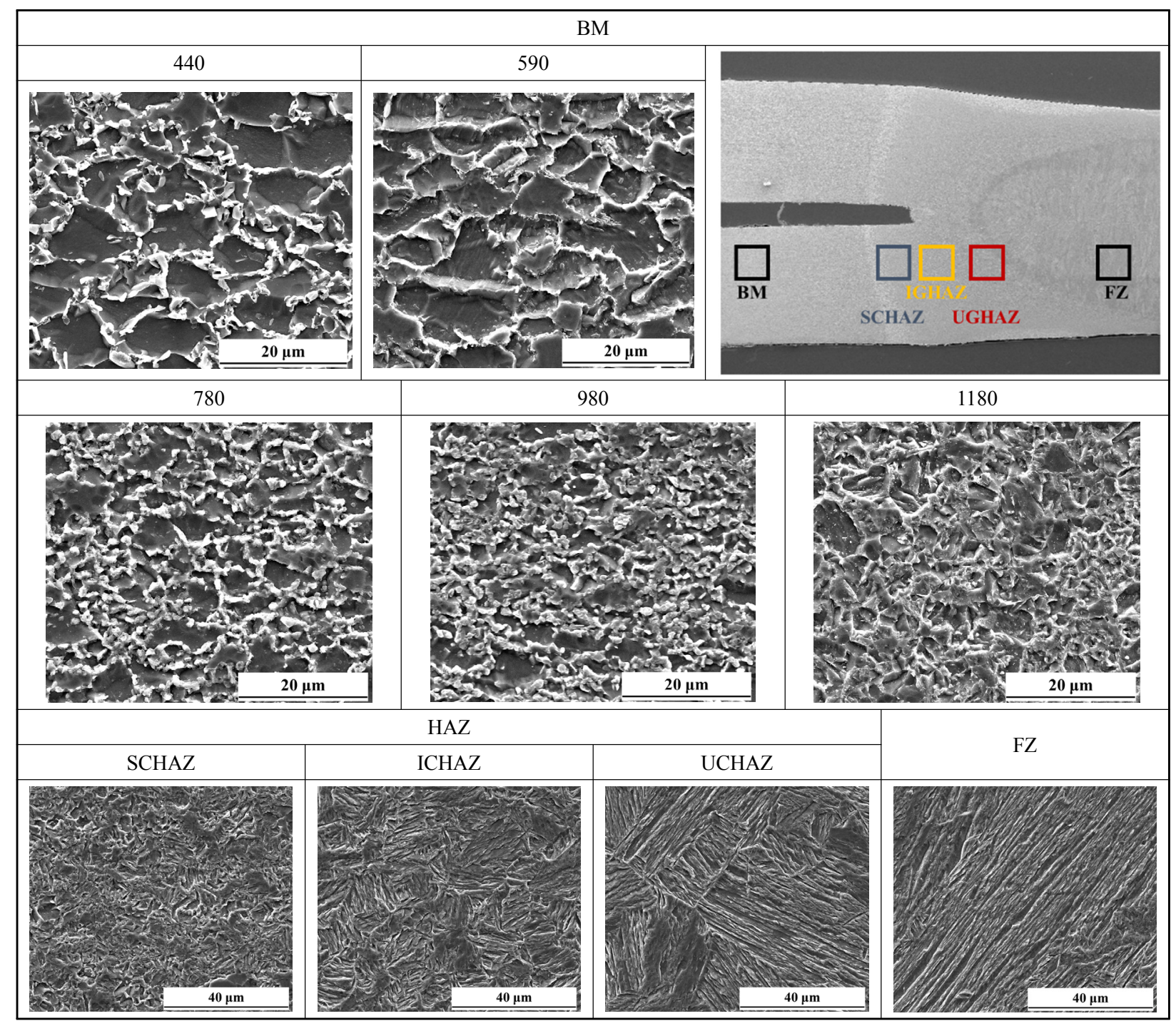

Fig. 6 Microstructure of resistance spot welds

structure of HAZ and FZ.

Investigation on the BM region of each steel grade revealed that the proportion of martensite increased and the size of grains decreased with increasing steel strength. During resistance spot welding, the FZ is fully melted first and transforms into austenite. After this process, the cooling water flowing through the electrode leads to rapid cooling to form martensite with high hardness values $^{21)}$. The microstructure of the HAZ changes based on the highest temperature reached during resistance spot welding. The UCHAZ, which is subjected to a maximum temperature above Ac3 and undergoes austenite transformation, consists of coarsened grains formed during rapid cooling and is composed of martensite. The ICHAZ, which experiences a maximum temperature between Ac1 and Ac3 where partial austenite transformation occurs, is comprised of martensite and ferrite with fine grains formed during quenching ${ }^{22)}$.
Finally, the SCHAZ undergoes a maximum temperature below Ac1, and martensite tempering occurs if martensite is present in the $\mathrm{BM}^{22}$. Furthermore, martensite tempering in the SCHAZ leads to the decrease in hardness in the HAZ. Based on this phenomenon, the reason for the decrease in hardness in the HAZ of 780 , 980, and $1180 \mathrm{MPa}$-grade steels can be confirmed.

\subsection{Hardness prediction using carbon equivalent (CE) equations}

As described in the introduction section, the aim of this work is to predict the failure modes and hardness of resistance spot welds using the chemical composition of the materials. To achieve this objective, the relationship between the hardness and strength of the material was established, as shown in equation (1).

$$
H V=c \sigma
$$


Table 4 Calculated strength using equation (1) and relative error

\begin{tabular}{|c|l|l|l|l|l|}
\hline $\begin{array}{c}\text { Steel grade } \\
(\mathrm{MPa})\end{array}$ & 440 & 590 & 780 & 980 & 1180 \\
\hline $\begin{array}{c}\text { Calculated } \\
\text { strength } \\
(\mathrm{MPa})\end{array}$ & 471.2 & 636.7 & 791.3 & 978.5 & 1185.9 \\
\hline $\begin{array}{c}\text { Relative } \\
\text { error (\%) }\end{array}$ & 7.08 & 7.92 & 1.45 & 0.15 & 0.50 \\
\hline
\end{tabular}

Here, $\sigma$ is the ultimate strength of the material, $\mathrm{HV}$ is the hardness of the material, and $c$ is a constant. For metals, a $c$ value of $1 / 3$ is commonly used ${ }^{23)}$. The strength calculated through equation (1) from the hardness values of steel grades studied in this work is listed in Table 4. As shown in Table 4, since the relative error between the strength values calculated from the hardness of the materials and actual strength values of the steel grades was all within $10 \%$, the strength of the BM was estimated using equation (1).

To estimate the hardness of the FZ, carbon equivalent (CE) equations were used. Equations (2)-(8) show the different $\mathrm{CE}$ equations that are commonly known. The element in each equation varies, and the coefficient associated with each element also differs. In all equations, 1 was universally used as the coefficient of the carbon element.

$$
\begin{aligned}
& C E Q(\text { Dearden })= \\
& C+\frac{M n}{6}+\frac{N i}{15}+\frac{C r}{5}+\frac{M o}{4}+\frac{V}{14}+\frac{C u}{13} \\
& C E Q(S u z u k u)= \\
& C+\frac{M n}{9}+\frac{N i}{40}+\frac{C r}{20}+\frac{M o}{8}+\frac{V}{10}+\frac{C u}{30} \\
& \operatorname{Pcm}(\text { Ito })= \\
& C+\frac{S i}{30}+\frac{M n}{20}+\frac{C u}{20}+\frac{N i}{60}+\frac{C r}{20} \\
& +\frac{M o}{15}+\frac{V}{10}+5 B \\
& C E(\text { Yurioka })= \\
& C+A(C)\left\{\begin{array}{l}
5 B+\frac{S i}{24}+\frac{M n}{6}+\frac{C u}{15}+\frac{N i}{15} \\
+\frac{C r+M o+N b+V}{5}
\end{array}\right\} \\
& A(C)=0.75+0.25 \tanh (20(C-0.12)) \\
& P L(\text { Kaizu })=C+\frac{S i}{50}+\frac{M n}{25}+\frac{P}{2}+\frac{C r}{25} \\
& P L(\text { Taka })=C+\frac{M n}{22}+14 B \\
& C E(\text { Marya })=C+\frac{S i}{30}+\frac{M n}{20}+2 P+4 S
\end{aligned}
$$

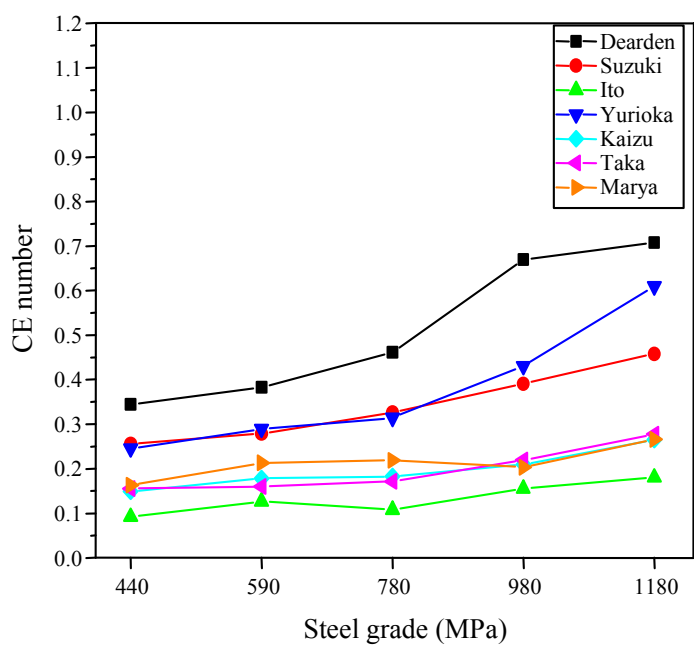

Fig. 7 Carbon equivalent (CE) according to various CE equations of materials with various steel grades

When CE was calculated using the equations above, the strength of the material and CE exhibited a linear relationship, as shown in Fig. 7. A regression equation was derived from the calculated $\mathrm{CE}$ to predict the hardness of the FZ and the minimum hardness of the HAZ. The regression equation and coefficient of determination are presented in Table 5.

$\mathrm{CE}$ equations with the highest coefficient of determination for predicting the hardness of the FZ and HAZ were kaizu and dearden equations, respectively. Therefore, kaizu and dearden equations were respectively used to predict the hardness of the FZ and HAZ, and the estimated hardness values and relative error are presented

Table 5 Regression equation and coefficient of determination $\left(\mathrm{R}^{2}\right)$ for predicting hardness of the $\mathrm{FZ}$ and HAZ using CE

\begin{tabular}{|c|c|c|c|}
\hline $\begin{array}{c}\text { CE } \\
\text { equation }\end{array}$ & \multicolumn{2}{|c|}{ Regression equation } & $\begin{array}{c}\text { Coefficient of } \\
\text { determination } \\
\left(\mathrm{R}^{2}\right)\end{array}$ \\
\hline \multirow{2}{*}{ Dearden } & $\mathrm{FZ}$ & $\mathrm{HV}=75.73 \times \mathrm{CE}+385.09$ & 0.55 \\
\cline { 2 - 4 } & $\mathrm{HAZ}$ & $\mathrm{HV}=359.95 \times \mathrm{CE}+69.54$ & 0.92 \\
\hline \multirow{2}{*}{ Suzuki } & $\mathrm{FZ}$ & $\mathrm{HV}=171.03 \times \mathrm{CE}+365.48$ & 0.70 \\
\cline { 2 - 4 } & $\mathrm{HAZ}$ & $\mathrm{HV}=699.87 \times \mathrm{CE}+14.97$ & 0.87 \\
\hline \multirow{2}{*}{ Ito } & $\mathrm{FZ}$ & $\mathrm{HV}=430.03 \times \mathrm{CE}+367.11$ & 0.82 \\
\cline { 2 - 4 } & $\mathrm{HAZ}$ & $\mathrm{HV}=1522.50 \times \mathrm{CE}+52.97$ & 0.77 \\
\hline \multirow{3}{*}{ Yurioka } & $\mathrm{FZ}$ & $\mathrm{HV}=106.54 \times \mathrm{CE}+383.70$ & 0.85 \\
\cline { 2 - 4 } & $\mathrm{HAZ}$ & $\mathrm{HV}=359.43 \times \mathrm{CE}+118.40$ & 0.72 \\
\hline \multirow{2}{*}{ Kaizu } & $\mathrm{FZ}$ & $\mathrm{HV}=367.37 \times \mathrm{CE}+351.71$ & 0.89 \\
\cline { 2 - 4 } & $\mathrm{HAZ}$ & $\mathrm{HV}=1229.20 \times \mathrm{CE}+12.48$ & 0.74 \\
\hline \multirow{2}{*}{ Taka } & $\mathrm{FZ}$ & $\mathrm{HV}=291.57 \times \mathrm{CE}+366.66$ & 0.79 \\
\cline { 2 - 4 } & $\mathrm{HAZ}$ & $\mathrm{HV}=1009.70 \times \mathrm{CE}+55.82$ & 0.70 \\
\hline \multirow{2}{*}{ Marya } & $\mathrm{FZ}$ & $\mathrm{HV}=418.27 \times \mathrm{CE}+335.04$ & 0.82 \\
\cline { 2 - 4 } & $\mathrm{HAZ}$ & $\mathrm{HV}=1227.80 \times \mathrm{CE}-6.82$ & 0.53 \\
\hline
\end{tabular}


Table 6 Measured and predicted hardness of FZ and HAZ with relative error

\begin{tabular}{|c|c|c|c|c|c|c|}
\hline \multicolumn{2}{|c|}{ Steel grade (MPa) } & 440 & 590 & 780 & 980 & 1180 \\
\hline \multirow{2}{*}{ Hardness of FZ (HV) } & Measured hardness & 407.4 & 424.2 & 414.2 & 421.9 & 451.9 \\
\cline { 2 - 8 } & Predicted hardness & 406.4 & 417.1 & 418.7 & 428.6 & 448.9 \\
\hline \multicolumn{2}{|c|}{ Relative error (\%) } & 0.25 & 1.68 & 1.08 & 1.58 & 0.66 \\
\hline \multirow{2}{*}{\begin{tabular}{c} 
Hardness of HAZ (HV) \\
\cline { 2 - 8 }
\end{tabular}} & Measured hardness & 170.4 & 217.4 & 254.8 & 316.2 & 311.6 \\
\hline \multicolumn{2}{|c|}{ Pelative error (\%) } & 193.3 & 207.1 & 235.5 & 310.4 & 324.1 \\
\hline
\end{tabular}

in Table 6. In the FZ, the relative error was the lowest in the $440 \mathrm{MPa}$-grade steel and was within $1.7 \%$ in all other steel grades, indicating that the predicted and measured hardness values were similar. In the HAZ, the relative error was the lowest in the $980 \mathrm{MPa}$-grade steel at $1.82 \%$ and the largest in the $440 \mathrm{MPa}$-grade steel at $13.44 \%$, and the overall relative error in the HAZ was greater than that in the FZ hardness prediction.

\subsection{Failure mode prediction}

The load applied to resistance spot welds during tensile loading was calculated to predict the failure modes of the spot welds subjected to tensile tests. As shown in Fig. 8(a), the nugget and HAZ regions of the resistance spot weld were assumed as a cylindrical shape. When $\mathrm{PF}$ occurred in this experiment, it was assumed that normal stress was applied to half of the cylindrical region of a material because the weld joint became separated at one of the two materials (Fig. 8(b)). When IF

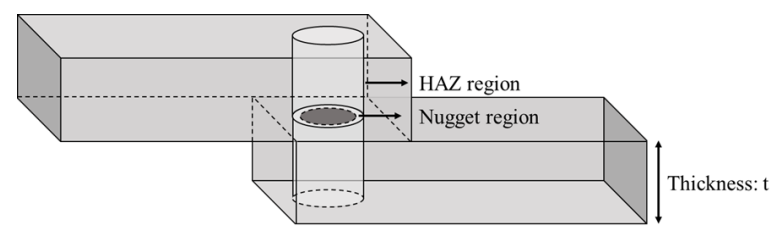

(a)

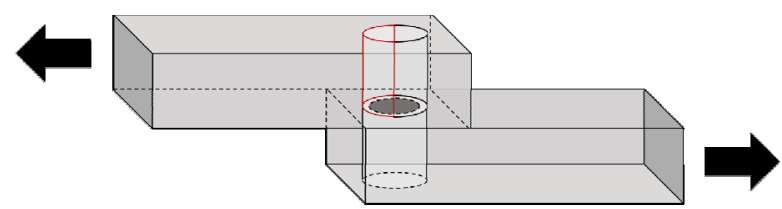

(b)

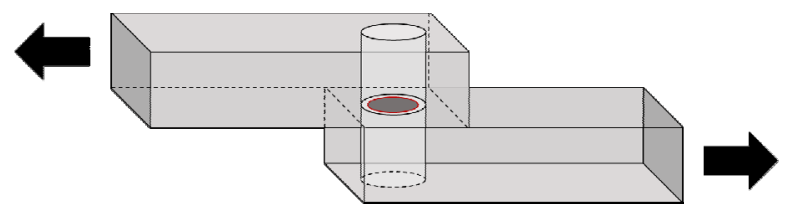

(c)

Fig. 8 Schematic images of (a) resistance spot welds, (b) pull out failure mode and (c) interfacial failure mode with tensile load direction occurred, it was assumed that shear stress was applied to the cross-sectional area of the spot weld due to fracture across the FZ (Fig. 8(c)). Considering the relevant region and stress during $\mathrm{PF}$ and IF, the load in each failure mode was calculated using equations (9-10) and indicated as $P_{P F}$ and $P_{I F}$, respectively.

$$
\begin{aligned}
& P_{P F}=\frac{d}{2} \pi t \sigma_{P F L} \\
& P_{I F}=\frac{d^{2}}{4} \pi \tau_{F Z}
\end{aligned}
$$

Here, $d$ is the nugget diameter and $t$ is the thickness of the material. When HAZ softening occurred, the HAZ diameter as opposed to the nugget diameter was used as d. HAZ diameter measurements on the spot welds of all materials were larger than the nugget diameter by approximately $2 \mathrm{~mm}$, such that the HAZ diameter was assumed as $\mathrm{d}+2$. $\sigma_{P F L}$ and $\tau_{F Z}$ are the normal stress at the failure location and shear stress in the FZ, respectively. The hardness at the failure location, hardness of the FZ, and equation (1) were used to calculate the stress. In general, $\mathrm{PF}$ occurred at the $\mathrm{BM}$ or $\mathrm{HAZ}$ region. In this experiment, assuming that the failure location of 780 , 980, and $1180 \mathrm{MPa}$-grade steels in which HAZ softening occurred was the HAZ and that the fracture of 440 and $590 \mathrm{MPa}$-grade steels without HAZ softening occurred at the BM, the minimum hardness of the HAZ and the hardness of the $\mathrm{BM}$ were respectively used as the hardness for calculating $\sigma_{P F L}$. On the other hand, only shear stress was present at spot welds when IF occurred, such that the hardness of the FZ was used to calculate the normal stress, which was converted to shear stress using the von Mises criterion shown in equation (11).

$$
\sigma=\frac{1}{\sqrt{3}} \tau
$$

Using $\sigma$ of the BM and the estimated hardness of the FZ and HAZ in equations (9-10), $P_{P F}$ and $P_{I F}$ at each 
Table 7 Calculated load of pull-out and interfacial failure mode according to welding currents

\begin{tabular}{|c|c|c|c|c|c|c|c|c|c|c|}
\hline $\begin{array}{l}\text { Steel grade } \\
(\mathrm{MPa})\end{array}$ & \multicolumn{2}{|c|}{440} & \multicolumn{2}{|c|}{590} & \multicolumn{2}{|c|}{780} & \multicolumn{2}{|c|}{980} & \multicolumn{2}{|c|}{1180} \\
\hline Load $(\mathrm{kN})$ & \multirow{2}{*}{$P_{P F}$} & \multirow{2}{*}{$P_{I F}$} & \multirow{2}{*}{$P_{P F}$} & \multirow{2}{*}{$P_{I F}$} & \multirow{2}{*}{$P_{P F}$} & \multirow{2}{*}{$P_{I F}$} & \multirow{2}{*}{$P_{P F}$} & \multirow{2}{*}{$P_{I F}$} & \multirow{2}{*}{$P_{P F}$} & \multirow{2}{*}{$P_{I F}$} \\
\hline Current & & & & & & & & & & \\
\hline \multirow{2}{*}{$4 \mathrm{kA}$} & 2.72 & 2.29 & 4.21 & 3.93 & 5.30 & 4.46 & 5.71 & 2.33 & 6.07 & 2.61 \\
\hline & \multicolumn{2}{|c|}{$>$} & \multicolumn{2}{|c|}{$>$} & \multicolumn{2}{|c|}{$>$} & \multicolumn{2}{|c|}{$>$} & \multicolumn{2}{|c|}{$>$} \\
\hline \multirow{2}{*}{$5 \mathrm{kA}$} & 3.58 & 5.90 & 5.13 & 7.49 & 5.70 & 5.95 & 7.71 & 6.61 & 7.49 & 2.50 \\
\hline & \multicolumn{2}{|c|}{$<$} & \multicolumn{2}{|c|}{$<$} & \multicolumn{2}{|c|}{$<$} & \multicolumn{2}{|c|}{$>$} & \multicolumn{2}{|c|}{$>$} \\
\hline \multirow{2}{*}{$6 \mathrm{kA}$} & 4.13 & 9.14 & 5.66 & 10.01 & 7.00 & 11.03 & 8.69 & 9.48 & 8.66 & 8.66 \\
\hline & \multicolumn{2}{|c|}{$<$} & \multicolumn{2}{|c|}{$<$} & \multicolumn{2}{|c|}{$<$} & \multicolumn{2}{|c|}{$<$} & \multicolumn{2}{|c|}{$=$} \\
\hline \multirow{2}{*}{$7 \mathrm{kA}$} & 4.64 & 12.74 & 6.37 & 14.00 & 7.48 & 13.31 & 9.96 & 14.00 & 9.68 & 12.00 \\
\hline & & & & & & & & & & \\
\hline $8 k 4$ & 5.19 & 17.34 & 6.43 & 14.37 & 7.96 & 15.80 & 10.74 & 17.21 & 11.36 & 18.70 \\
\hline 0 KA & & & & & & & & & & \\
\hline $0+1$ & 5.58 & 21.02 & 7.61 & 22.52 & 8.52 & 18.94 & 11.52 & 20.76 & 11.01 & 17.15 \\
\hline $9 \mathrm{KA}$ & & & & & & & & & & \\
\hline 101 & 5.51 & 20.35 & 6.93 & 17.58 & 7.85 & 15.20 & 11.86 & 22.41 & 13.09 & 27.14 \\
\hline $10 \mathrm{~A}$ & & & & & & & & & & \\
\hline $1 \mathrm{kA}$ & 5.60 & 21.25 & 7.91 & 24.97 & 9.88 & 27.91 & 11.91 & 22.65 & 12.74 & 25.27 \\
\hline $11 \mathrm{KA}$ & & & & & & & & & & \\
\hline
\end{tabular}

welding current value were calculated and compared (Table 7). When $P_{P F}$ is greater than $P_{I F}$, it is assumed that IF occurs due to the insufficient driving force for the fracture to propagate from the failure location where PF would take place (gray). In the opposite case, it is assumed that PF occurs (dark gray). Comparison with the actual experimental results shown in Table 3 showed that the experimental and predicted results were consistent across all regions except at $5 \mathrm{kA}$ in the $590 \mathrm{MPa}$-grade steel, $5 \mathrm{kA}$ in the $780 \mathrm{MPa}$-grade steel, and $6 \mathrm{kA}$ in the $980 \mathrm{MPa}$-grade steel. The difference between the loads $P_{P F}$ and $P_{I F}$ at $5 \mathrm{kA}$ in the $590 \mathrm{MPa}$-, $5 \mathrm{kA}$ in the $780 \mathrm{MPa}$-, and $6 \mathrm{kA}$ in the $980 \mathrm{MPa}$-grade steels was $2.36,0.25$, and $0.79 \mathrm{kN}$, respectively. Since the same hardness is used when calculating $P_{P F}$ and $P_{I F}$ at each welding current, the nugget diameter plays a dominant role in determining $P_{P F}$ and $P_{I F}$. During this step, it is possible that an error arises during the process of measuring the nugget diameter, and this may be the source of discrepancy between the predicted and experimental results. The measurement error associated with the nugget diameter can be minimized by processing the center of the nugget during cross-sectioning of the weld nugget or by increasing the number of samples measured.

\section{Conclusion}

In this work, resistance spot welding was conducted on $440 \mathrm{MPa}$-grade steel (low strength steel) to 1180
MPa-grade steel (high strength steel), followed by investigation on the mechanical properties and prediction on the failure modes. To evaluate the mechanical properties, tensile testing was performed, and the nugget size and hardness were measured. The hardness of the FZ and HAZ were estimated using the chemical composition of the materials, and failure modes were predicted by comparing the calculated load occurring at the spot welds.

1) As the welding current increased, the tensile shear strength increased and eventually approached a steady value beyond a certain current value. Similar to tensile strength, the nugget diameter also increased and leveled off with increasing welding current. Based on these findings, it was confirmed that the nugget diameter has a significant effect on the strength of spot welds.

2) Hardness measurement results showed that the hardness of the BM increased in the order of 440, 590, 780, 980, and1180 MPa-grade steel, while that of the FZ was the lowest in the $440 \mathrm{MPa}$-grade steel, highest in the $1180 \mathrm{MPa}$-grade steel, and similar across 590, 780 , and $980 \mathrm{MPa}$-grade steels. In addition, HAZ softening occurred in 780, 980, and $1180 \mathrm{MPa}$-grade steels.

3) Various $C E$ equations were used to calculate the $\mathrm{CE}$ of each material. Kaizu and Dearden equations were respectively used to estimate the hardness of the FZ and HAZ. The predicted hardness results were shown to be similar to the experimental values.

4) Using the estimated hardness values, the load occurring at the region surrounding the spot welds during 
the application of tensile load was calculated for each failure mode. The calculated $P_{P F}$ and $P_{I F}$ were compared to predict the failure mode, and these results were similar to those from actual experiments.

\section{Acknowledgments}

This work was supported by Technology Innovation Industrial Program funded by the Ministry of Trade, Industry and Energy (MOTIE, Korea) [Development of Car Body Modularization Technology using Advanced Cold Forming and Welding Technologies of Low Density GIGA Grade Light Steel Sheets].

ORCID: Heewon Cho: https://orcid.org/0000-0002-9644-6618 ORCID: Sangwoo Nam: https://orcid.org/0000-0002-2486-4941 ORCID: Minjung Kang: https://orcid.org/0000-0003-1894-4301 ORCID: Munjin Kang: https://orcid.org/0000-0003-0598-0848 ORCID: Young-Min Kim: https://orcid.org/0000-0003-3573-8753

\section{References}

1. K. Sugimoto, T. Iida, J. Sakaguchi and T. Kashima, Retained austenite characteristics and tensile properties in a TRIP type bainitic sheet steel, ISIJ Int. 40(9) (2000) 902-908.

https://doi.org/10.2355/isijinternational.40.9021.

2. J. Mortimer, Jaguar uses X350 car to pioneer use of self-piercing rivets, Ind. Robot 28(3) (2001) 192-198. https://doi.org/10.1108/01439910110389344

3. M. Pouranvari, S. M. Mousavizadeh, S. P. H. Marashi, M. Goodarzi and M.Ghorbani, Influence of fusion zone size and failure mode on mechanical performance of dissimilar resistance spot welds of AISI 1008 low carbon steel and DP600 advanced high strength steel, Mater. Design 32(3) (2011) 1390-1398. https://doi.org/10.1016/j.matdes.2010.09.010

4. M. Jeanneau and P. Pichant, The trends of steel products in the European automotive industry, Metall. Res. Technol. 97(11) (2000) 1399-1408. https://doi.org/10.1051/metal:2000118

5. B. Smith, A. Spulber, S. Modi and T. Fiorelli, Technology roadmaps: Intelligent mobility technology, materials and manufacturing processes, and light duty vehicle propulsion, Technical Report; Center for Automotive Research, Ann Arbor, MI, USA (2017).

6. R. Schultz and A. Abraham, Metallic material trends for North American light vehicles, Great Designs in steel seminar, May, Livonia, MI, USA (2009).

7. S. Singh and T. Nanda, A Review: Production of Third Generation Advance High Strength Steels, Int. J. Sci. Res. 2(9) (2014) 388-392.

8. I. Hwang, H. Yoon, D. Kim, M. Kang, J. D. Kim and Y. M. Kim, Resistance spot weldability of low density lightweight steel according to electrode shape, J. Weld. Join. 35(2) (2017) 52-57.

https://doi.org/10.5781/JWJ.2017.35.2.8

9. S. G. Choi, I. Hwang, M. Kang, S. Hyun and Y. M. Kim, Optimization of Welding Parameters in Resistance Spot Welding of $980 \mathrm{MPa}$ Grade GA Steel Sheet using Multi-Response Surface Methodology, J. Weld. Join. 36(4) (2018) 63-69.

https://doi.org/10.5781/JWJ.2018.36.4.7

10. Y. J. Chao, Ultimate strength and failure mechanism of resistance spot weld subjected to tensile, shear, or combined tensile/shear loads, J. Eng. Mater. Technol. 125(2) (2003) 125-132.

https://doi.org/10.1115/1.1555648

11. T. B. Hilditch, J.G. Speer and D. K. Matlock, Effect of susceptibility to interfacial fracture on fatigue properties of spot-welded high strength sheet steel, Mater. Design 28(10) (2007) 2566-2576. https://doi.org/10.1016/j.matdes.2006.10.019

12. D. W. Zhao, Y.X. Wang, L. Zhang and P. Zhang, Effects of electrode force on microstructure and mechanical behavior of the resistance spot welded DP600 joint, Mater. Design 50 (2013) 72-77.

https://doi.org/10.1016/j.matdes.2013.02.016

13. H. Zhang, A. Wei, X. Qiu and J. Chen, Microstructure and mechanical properties of resistance spot welded dissimilar thickness DP780/DP600 dual-phase steel joints, Mater. Design 54 (2014) 443-449. https://doi.org/10.1016/j.matdes.2013.08.027

14. F. Nikoosohbat, S. Kheirandish, M. Goodarzi, M. Pouranvari and S. P. H. Marashi, Microstructure and failure behaviour of resistance spot welded DP980 dual phase steel, Mater. Sci. Technol. 26(6) (2010) 738-744. https://doi.org/10.1179/174328409X414995

15. M. Goodarzi, S. P. H. Marashi, and M. Pouranvari, Dependence of overload performance on weld attributes for resistance spot welded galvanized low carbon steel, J. Mater. Process.Tech. 209(9) (2009) 4379-4384. https://doi.org/10.1016/j.jmatprotec.2008.11.017

16. H. Lee, N. Kim, and T. S. Lee, Overload failure curve and fatigue behavior of spot-welded specimens, Eng. Fract. Mech. 72(8) (2005) 1203-1221. https://doi.org/10.1016/j.engfracmech.2004.07.013

17. M. Pouranvari, S. P. H. Marashi and D. S. Safanama, Failure mode transition in AHSS resistance spot welds. Part II: Experimental investigation and model validation, Mater. Sci. Eng. A 528(29-30) (2011) 83448352.

https://doi.org/10.1016/j.msea.2011.08.016

18. Y. P. Yang, S. Khurana and F. Orth, Development of an Integrated Computational Model to Predict the Performance of AHSS Spot Welds: Methodology and Challenges, Sheet Metal Welding Conference XII, May, Livonia, MI, USA (2015). 
19. D. J. Radakovic and M. Tumuluru. Predicting resistance spot weld failure modes in shear tension tests of advanced high-strength automotive steels, Weld. J. 87(4) (2008) 96-s - 105-s.

20. S. G. Choi, I. Hwang, Y. M. Kim, B. Kang and M. Kang, Prediction of the Weld Qualities Using Surface Appearance Image in Resistance Spot Welding, Metals 9(8) (2019) 831-1 - 831-14. https://doi.org/10.3390/met9080831

21. M. Tamizi, M. Pouranvari, and M. Movahedi. Welding metallurgy of martensitic advanced high strength steels during resistance spot welding, Sci. Techno. Weld.
Join. 22(4) (2017) 327-335.

https://doi.org/10.1080/13621718.2016.1240979

22. M. I. Khan, M. L. Kuntz, E. Biro and Y. Zhou, Microstructure and mechanical properties of resistance spot welded advanced high strength steels, Mater. Trans. 49(7) (2008) 1629-1637.

https://doi.org/10.2320/matertrans.MRA2008031

23. P. Zhang, S.X. Li and Z.F. Zhang, General relationship between strength and hardness, Mater. Sci. Eng. A 529(25) (2011) 62-73.

https://doi.org/10.1016/j.msea.2011.08.061 


\title{
소재의 화학 성분에 따른 저항 점 용접부의 파단 모드 예측 \\ Predicting Failure Modes of Resistance Spot Welds from the Chemical Composition of Materials
}

\author{
조희 원 ${ }^{*}$ - 남상우 ${ }^{* *, * * *}$ - 강민정 ${ }^{* * *}$ - 강문진 ${ }^{* * *} \cdot$ 김영민 ${ }^{* * *}$ \\ *G화학 Pack DFM 검증팀 \\ **서울대학교 재료공학부 \\ ***한국생산기술연구원 뿌리기술연구소 부품기능연구부문
}

\section{1. 서 론}

저항 점 용접은 공정 시간이 짧아 생산성이 높으며, 차체에 약 $70 \%$ 이상 사용되는 공정이다 ${ }^{1-3)}$. 저항 점 용접의 용접 품질을 확인하기 위해, 최대 하중, 파단 모드, 너깃 지름 등을 관찰한다. 이런 요소들 관찰하기 위해서는 파괴 검사가 필수적이나, 차체 구조물에서 파 괴 검사는 수행되기 어려우며, 많은 비용과 시간이 소 요된다는 문제점이 있다.

최근 배기가스 배출 감소를 위한 환경규제가 계속해 서 요구되고 있다. 자동차 산업에서는 자동차의 경량화 를 통해, 배기가스 배출량을 감소하고 연비 증가가 가 능하다 ${ }^{4)}$. 최근 자동차 차체에는 알루미늄, 고강도강, $\mathrm{CFRP}$ 등의 소재가 사용된다 ${ }^{5)}$. 얇은 두께에 비해 높 은 강도를 가지고 있는 고강도 강은 차체의 안전성과 경량화의 수요로 인하여, 최근 자동차 산업에서 널리 적용되고 있다 ${ }^{6)}$. 고강도 강은 높은 기계적 성질을 위 해 다양한 합금 원소들이 첨가되는데, 이로 인해 용접 성이 나빠지는 문제가 발생한다 7.8$)$. 고강도 강은 기존 에 사용되던 강과는 달리, 비교적 낮은 전류에서도 날 림이 발생하므로 적정 용접 조건의 범위가 좁다. 또한 너깃 크기가 충분히 커졌음에도 불구하고, 풀 아웃 파 단(pull out failure)보다 계면 파단(interfacial failure)의 발생이 빈번하다 ${ }^{9-11)}$.

저강도 강뿐만 아니라 새롭게 개발되고 있는 강에 대 하여 기계적 특성을 평가하기 위한 연구가 꾸준히 진행 되어 왔다. Zhao는 DP600 강의 저항 점 용접부에 대 하여 인장 전단 시험을 진행하고, 가압력이 인장 전단 강도와 파괴 에너지 흡수에 미치는 영향, 파단모드 및 미세구조에 대해 연구를 수행하였다 ${ }^{12)}$. 그 결과, 너깃 크기가 파괴모드 그리고 파괴에너지의 영향을 받는다고 하였다. Zhang은 DP780과 DP600 소재를 저항 점
용접을 수행한 뒤, 미세 구조와 기계적 성질에 대해 연 구하였다 ${ }^{13)}$. 파단모드는 주로 너깃 크기에 의존하며, 파단모드가 계면 파단에서 풀 아웃 파단으로 전이되는 임계 너깃 지름을 확인하였다. Nikoosohbat은 앞선 연구에서 사용된 소재보다 높은 강도의 소재인 DP980 을 사용하여 저항 점 용접을 수행한 뒤, 기계적 특성과 미세구조를 관찰하고, 파괴거동에 대해 연구하였다 ${ }^{14)}$. 일반적으로 풀 아웃 파단모드에서 파괴는 연화가 발생 한 열 영향부와 모재 사이에서 발생한다고 하였다. 또 한, DP980 소재의 경우에 $4 \sqrt{ } \mathrm{t}$ 의 기준이 풀 아웃 파 단을 보장하기에 부족하므로, 고강도 강에 대해 새로운 용접 품질 기준을 세워야 한다고 하였다. 이외에도 고 강도 강에서 풀 아웃 파단보다 계면 파단에 높은 민감 성을 보이는 연구가 다수 진행되었다 ${ }^{15-17)}$.

저항 점 용접의 용접 품질을 파괴하지 않고 예측하는 연구에 대해서도 계속해서 진행되었다. Yang은 DP590 소재에 대하여, 저항 점 용접의 성능 예측을 위한 계산 모델을 개발하였다 ${ }^{18)}$. 이 모델은 용접 공정 모델과 로 컬 모델로 구성되며, 용접부의 잔류 응력과 소성 변형 을 예측하였다. Radakovic와 Tumuluru는 DP590, DP780, TRIP780 소재에 대하여 저항 점 용접을 수 행하고, $\mathrm{FEM}$ 을 이용하여 파단모드를 예측하였다 ${ }^{19)}$. 해석을 통해, 파단모드에 따라 발생하는 소성 변형량과 예상 파단 하중을 계산하였으며, $\mathrm{FEM}$ 을 기반으로 유 도된 식은 풀 아웃 파단을 발생시키기 위한 힘이 인장 강도뿐만 아니라, 강의 두께, 너깃 직경과 비례하는 것 을 확인하였다. 이처럼 해석 프로그램을 사용하여 저항 점 용접부의 품질 예측하는 방법 이외에도, 용접부의 겉보기 이미지와 인공지능 구조 중 하나인 $\mathrm{CNN}\left(\mathrm{con}^{-}\right.$ volution neural network)를 이용하여 인장 전단 강 도, 너깃 지름, 파단 모드, 날림 발생을 예측하였다 ${ }^{20)}$. 하지만 컴퓨터를 통해 예측하는 해석이나 인공지능을 이용하는 방법은 많은 시간이 소요된다. 추가적으로 인 
공지능을 사용하여 예측하는 방법은 많은 입력 데이터가 필요하기 때문에, 전수 실험이 선행되어야 한다. 앞서 소 개한 연구에서 사용한 소재의 최대 강도는 $980 \mathrm{MPa}$ 급이었으며, 대체적으로 한 가지의 소재에 대해서만 수 행되었다. 그리고 용접 품질 예측을 위한 모델의 대상 역시 한 가지의 소재에 대한 것이거나 저강도 강부터 고강도 강을 모두 포함하지 않고 있다.

본 연구에서는 저강도 강부터 초고강도 강을 모두 포 함하여, 저항 점 용접을 수행하여 용접부의 기계적 특 성을 관찰하였다. 또한, 용접부를 파괴하지 않고도 용 접 품질을 확인하기 위해, 소재의 화학 성분을 이용하 여 너깃 크기와 경도를 예측하였다. 그리고 예측한 값 을 이용하여 파단 모드를 예측한 뒤, 실제 파단 모드와 비교하였다.

\section{2. 사용 재료 및 실험 방법}

\section{1 사용 재료}

본 연구에서는 두께가 모두 $1 \mathrm{~mm}$ 로 동일한 440, $590,780,980,1180 \mathrm{MPa}$ 급 강재를 사용하여 저항 점 용접을 수행하였다. 사용한 소재의 이름은 소재 강 도를 사용하였고, 화학적 조성은 Table 1 과 같다.

\section{2 실험 방법}

용접 전원은 medium frequency direct current (MFDC) 저항 점 용접기를 사용하였으며, 본 연구에 서 사용된 용접전극의 형상을 Fig. 1(a) 에 나타내었 다. 용접전극은 돔 형태의 용접전극을 사용하였으며, 선단직경과 선단반경은 각각 $6 \mathrm{~mm}$ 와 $40 \mathrm{~mm}$ 이다 (Fig. 1(a)), 용접 전류는 $4 \mathrm{kA}$ 부터 $12 \mathrm{kA}$ 를 사용하 였고, 가압력은 $3 \mathrm{kN}$, 용접시간은 $333 \mathrm{~ms}$ 으로 고정 하였다 (Table 2). 저항 점 용접 수행 후 용접부의 용 접성 평가를 위해, 인장전단강도, 너깃 사이즈와 경도 를 측정하였다. 인장 전단 시험은 $\mathrm{AG}-300 \mathrm{kNXPlus}$

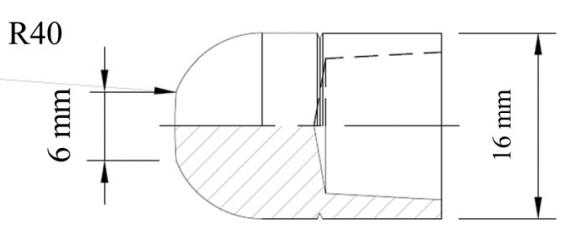

(a)

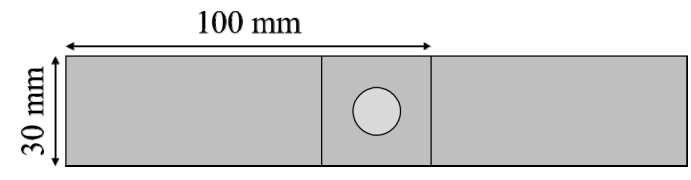

(b)

Fig. 1 Schematic images of (a) electrode shape and (b) specimen size

Table 2 Resistance spot welding conditions used in this study

\begin{tabular}{|c|c|c|c|c|}
\hline $\begin{array}{c}\text { Electrode face } \\
\text { diameter }\end{array}$ & $\begin{array}{c}\text { Electrode } \\
\text { force }\end{array}$ & $\begin{array}{c}\text { Welding } \\
\text { current }\end{array}$ & $\begin{array}{c}\text { Welding } \\
\text { time }\end{array}$ & $\begin{array}{c}\text { Holding } \\
\text { time }\end{array}$ \\
\hline $6 \mathrm{~mm}$ & $3 \mathrm{kN}$ & $4-12 \mathrm{kA}$ & $333 \mathrm{~ms}$ & $167 \mathrm{~ms}$ \\
\hline
\end{tabular}

(Shimazu, Japan)를 사용하여 $10 \mathrm{~mm} / \mathrm{min}$ 의 변형 률로 수행하였다. 인장시험편은 KS B 0851(점 용접 이음의 전단인장시험 방법) 규격에 맞춰 길이 $100 \mathrm{~mm}$, 폭 $30 \mathrm{~mm}$ 크기의 소재를 $30 \mathrm{~mm}$ 만큼 겹친 뒤 용접을 수행하였다 (Fig. 1(b)). 경도는 HM-101(Mitutoyo, Japan)을 사용하여 압입 하중은 $200 \mathrm{~g}$ 으로 측정하 였다. 너깃사이즈는 용접 후 너깃 중앙부를 단면 가공 하여 에칭 후 광학현미경을 사용하여 측정하였다. 파단 형상은 인장전단시험 결과를 통해 결정하였다.

\section{3. 실험 결과 및 고찰}

\section{1 용접부 기계적 특성}

Fig. 2 와 3 은 각 소재 별 용접부에 대하여, 용접 전 류 변화에 따른 인장 전단 강도와 너깃 사이즈를 보여 주고 있다. 인장전단강도와 너깃 사이즈 두 값 모두 전

Table 1 Chemical composition (wt. \%) of the material used in this study

\begin{tabular}{|c|c|c|c|c|c|c|c|c|c|c|}
\hline \multirow{2}{*}{$\begin{array}{c}\text { Steel } \\
\text { grade }\end{array}$} & \multicolumn{9}{|c|}{ Chemical composition } \\
\cline { 2 - 13 } & $\mathrm{C}$ & $\mathrm{Si}$ & $\mathrm{Mn}$ & $\mathrm{Ni}$ & $\mathrm{Cr}$ & $\mathrm{Mo}$ & $\mathrm{Cu}$ & $\mathrm{V}$ & $\mathrm{Nb}$ & $\mathrm{B}$ \\
\hline 440 & 0.088 & 0.019 & 1.480 & 0.015 & 0.031 & 0.007 & 0.013 & 0.003 & 0.004 & $<0.001$ \\
\hline 590 & 0.079 & 1.350 & 1.770 & 0.013 & 0.028 & 0.006 & 0.012 & 0.004 & 0.006 & $<0.001$ \\
\hline 780 & 0.067 & 1.120 & 2.290 & 0.013 & 0.031 & 0.020 & 0.019 & 0.003 & 0.023 & $<0.001$ \\
\hline 980 & 0.071 & 0.470 & 2.330 & 0.023 & 0.890 & 0.120 & 0.025 & 0.006 & 0.053 & 0.003 \\
\hline 1180 & 0.130 & 0.130 & 2.620 & 0.031 & 0.680 & 0.008 & 0.018 & 0.006 & 0.030 & 0.002 \\
\hline
\end{tabular}




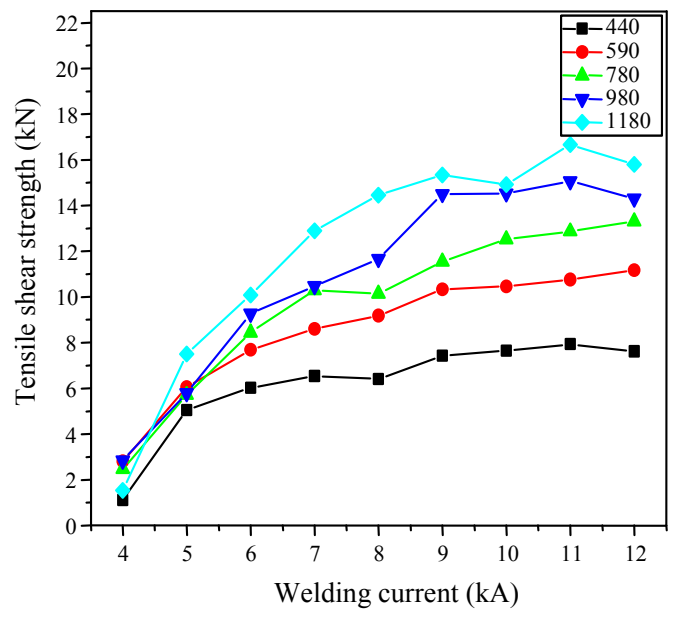

Fig. 2 Tensile shear strength according to welding current

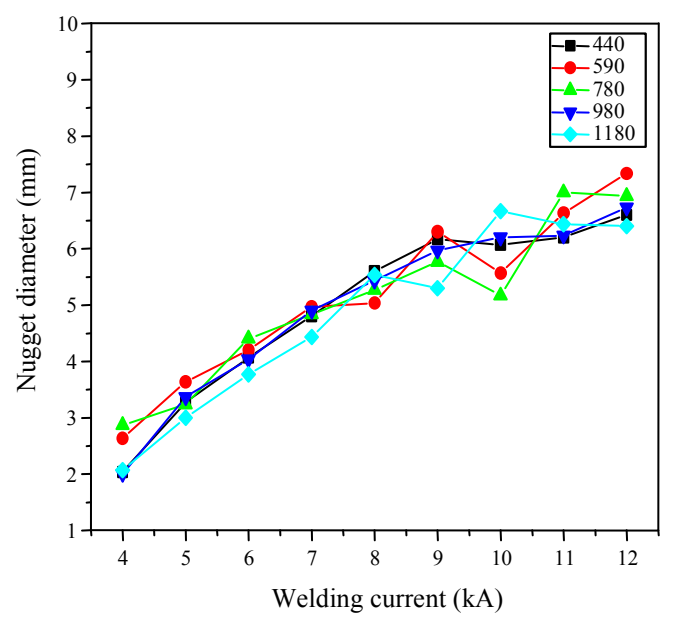

Fig. 3 Nugget diameter according to welding current

류가 증가함에 따라 증가하는 경향을 보였으나, 인장전 단강도의 경우는 $9 \mathrm{kA}$ 이상의 전류에서는 대체적으로

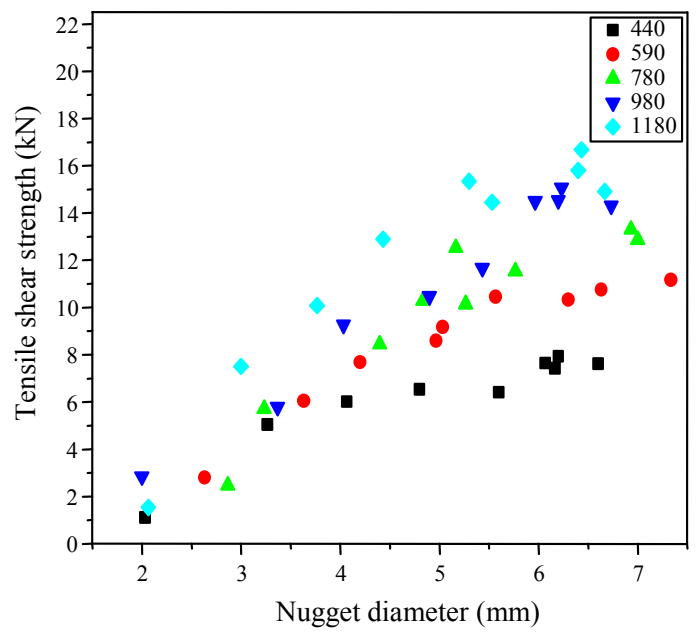

Fig. 4 Tensile shear strength according to nugget diameter

수렴하는 형태를 보여주었다. 너깃사이즈의 경우에도 $1180 \mathrm{MPa}$ 급 강재를 제외하고는 $9 \mathrm{kA}$ 의 전류까지는 증가하는 형태를 보여주고 있으며, 그 이상의 전류에서 는 증가폭이 감소하거나 수렴하는 형태를 나타내고 있 다. Fig. 4는 너깃 사이즈와 인장전단강도의 상관관계 를 보여주고 있는데, 기울기는 다르지만 모든 강종에 대하여 너깃사이즈가 증가함에 따라 인장 전단 강도가 선형적으로 증가한다는 사실을 보여주고 있다.

인장 전단 시험 결과, 계면파단(interfacial failure, IF) 및 버튼 파단(pull-out failure, $\mathrm{PF}$ )의 파단 모 드가 발생하였고, 소재 별 용접부에 대하여, 전류에 따 른 파단 모드를 Table 3 에 나타내었다. $440 \mathrm{MPa}$ 급 강재의 경우, 가장 낮은 전류 범위인 $5 \mathrm{kA}$ 에서 $\mathrm{PF}$ 가 발생하였고, $590,780,1180 \mathrm{MPa}$ 급 강재는 $6 \mathrm{kA}$, $980 \mathrm{MPa}$ 급 강재는 $7 \mathrm{kA}$ 에서 $\mathrm{PF}$ 가 발생하였다.

각 소재의 경도 프로파일 측정결과를 Fig. 5 에서 보

Table 3 Failure mode of welds with steel grade according to welding current

\begin{tabular}{|c|c|c|c|c|c|}
\hline Steel grade $(\mathrm{MPa})$ & 440 & 590 & 780 & 980 & 1180 \\
\hline Current & & & & & \\
\hline $4 \mathrm{kA}$ & $\mathrm{IF}$ & IF & IF & IF & IF \\
\hline $5 \mathrm{kA}$ & PF & IF & IF & IF & IF \\
\hline $6 \mathrm{kA}$ & $\mathrm{PF}$ & $\mathrm{PF}$ & $\mathrm{PF}$ & IF & $\mathrm{PF}$ \\
\hline $7 \mathrm{kA}$ & $\mathrm{PF}$ & $\mathrm{PF}$ & PF & $\mathrm{PF}$ & PF \\
\hline $8 \mathrm{kA}$ & $\mathrm{PF}$ & $\mathrm{PF}$ & $\mathrm{PF}$ & $\mathrm{PF}$ & PF \\
\hline $9 \mathrm{kA}$ & $\mathrm{PF}$ & $\mathrm{PF}$ & $\mathrm{PF}$ & $\mathrm{PF}$ & $\mathrm{PF}$ \\
\hline $10 \mathrm{kA}$ & $\mathrm{PF}$ & $\mathrm{PF}$ & PF & $\mathrm{PF}$ & PF \\
\hline $11 \mathrm{kA}$ & $\mathrm{PF}$ & $\mathrm{PF}$ & $\mathrm{PF}$ & $\mathrm{PF}$ & $\mathrm{PF}$ \\
\hline $12 \mathrm{kA}$ & $\mathrm{PF}$ & PF & $\mathrm{PF}$ & $\mathrm{PF}$ & $\mathrm{PF}$ \\
\hline
\end{tabular}

본 논문은 독자의 이해를 돕기위하여 영문논문을 국문으로 번역하여 게재한 논문입니다. 저자는 본 논문으로 연구업적과 같은 실적에 중복으로 지원받거나 인정받을 수 없음을 알려드립니다. 


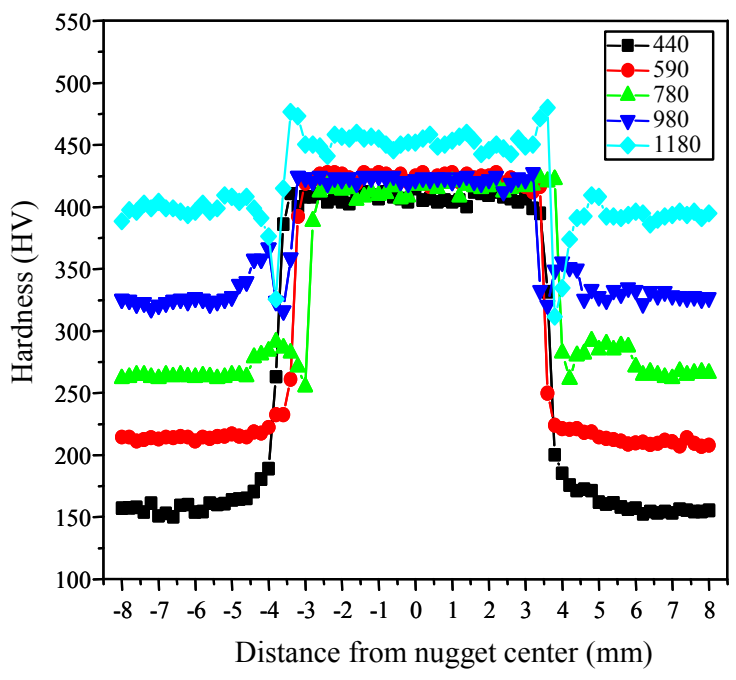

\begin{tabular}{|c|c|c|c|c|c|c|}
\hline \multicolumn{2}{|c|}{ Steel grade $(\mathrm{MPa})$} & 440 & 590 & 780 & 980 & 1180 \\
\hline \multirow{3}{*}{$\begin{array}{c}\text { Hardness } \\
(\mathrm{HV})\end{array}$} & $\mathrm{BM}$ & 157.1 & 212.2 & 263.8 & 326.2 & 395.3 \\
\cline { 2 - 7 } & $\mathrm{FZ}$ & 407.4 & 424.2 & 414.2 & 421.9 & 451.9 \\
\cline { 2 - 7 } & $\mathrm{HAZ}$ & 170.4 & 217.4 & 254.8 & 316.2 & 311.6 \\
\hline
\end{tabular}

Fig. 5 Hardness profile of welded specimens with different steel grade

여주고 있다. 열영향부(heat affected zone, HAZ)의 대표 경도 값으로는 HAZ softening이 발생하지 않았 을 경우에는 $\mathrm{HAZ}$ 영역의 평균 경도를 사용하였으며, HAZ softening이 발생하였을 경우에는 HAZ 영역에 서의 최소 경도를 사용하였다. 각각의 강도에 따른 소재 별 모재(Base material, $\mathrm{BM}$ )의 경도는 각각 157.1, $212.2,263.8,326.2,395.3 \mathrm{HV}$ 로, 모재 강도가 증가함에 따라 경도가 증가하였다. Fusion zone (FZ) 경도는 소재별로 각각 407.4, 424.2, 414.2, 421.9, $451.9 \mathrm{HV}$ 로, $440 \mathrm{MPa}$ 급 강재가 가장 낮고, $1180 \mathrm{MPa}$ 급 강재가 가장 높았으며, 590,780 및 $980 \mathrm{MPa}$ 급 강 재는 유사한 경도 값을 보였다. 780, 980, $1180 \mathrm{MPa}$ 급 강재는 $\mathrm{HAZ}$ 에서 $\mathrm{BM}$ 보다 경도가 감소하는 $\mathrm{HAZ}$ softening 현상이 발생하였고, 그때의 최소 경도 값은 254.8, 316.2, 311.6 HV였다. 780, 980, $1180 \mathrm{MPa}$ 급 강재에서 $\mathrm{BM}$ 의 경도와 $\mathrm{HAZ}$ 의 최소 경도의 차이 값은 각각 $9,10,84 \mathrm{HV}$ 으로, $1180 \mathrm{MPa}$ 급 강재에 서의 감소량이 가장 컸다.

\section{2 용접부 미세조직 특성}

Fig. 6은 저항 점 용접부의 미세구조를 보여주고 있 다. 저항 점 용접부의 미세구조는 $\mathrm{BM}, \mathrm{HAZ}, \mathrm{FZ}$ 총 세 가지로 구분할 수 있다. 이때, HAZ는 FZ와의 거리
에 따라 $\mathrm{FZ}$ 와 가장 가까운 $\mathrm{UCHAZ}$ (upper critical $\mathrm{HAZ}$ ), $\mathrm{BM}$ 과 가장 가까운 $\mathrm{SCHAZ}$ (sub critical $\mathrm{HAZ}$ ), UCHAZ 와 SCHAZ 사이에 있는 ICHAZ (inter critical HAZ) 총 3가지로 분류할 수 있다. $\mathrm{HAZ}$ 와 $\mathrm{FZ}$ 의 미세구조는 $440 \mathrm{MPa}$ 급 강의 $\mathrm{HAZ}$ 와 $\mathrm{FZ}$ 만을 그림에 나타내었다.

각각의 소재에서 $\mathrm{BM}$ 영역을 관찰하였을 때, 소재의 강도가 증가함에 따라, 마르텐사이트의 분율이 증가하 고, 결정립의 크기가 감소하였다. $\mathrm{FZ}$ 는 저항 점 용접 의 공정 중, 먼저 완전 용융되어 오스테나이트로 변태 된다. 그 후 전극에 흐르는 냉각수로 인해 높은 냉각 속도로 냉각이 일어나 마르텐사이트가 형성되고 높은 경도 값을 가지게 된다 ${ }^{21)}$. $\mathrm{HAZ}$ 는 저항 점 용접 공정 중에 도달하는 최대 온도에 따라 미세구조가 달라진다. $\mathrm{UCHAZ}$ 는 최대 온도가 Ac3 이상으로, 오스테나이트 화를 겪으며 높은 냉각속도로 조대화된 결정립이 형성 되고 마르텐사이트로 구성된다. ICHAZ는 최대 온도가 Ac1과 Ac3 사이로, 부분적으로 오스테나이트화를 겪 고 냉각이 되면서 조밀한 결정립이 형성되고, 마르텐사 이트와 페라이트로 구성된다 ${ }^{22)}$. 마지막으로, SCHAZ 는 최대 온도가 $\mathrm{Ac} 1$ 이하로, 모재에 마르텐사이트가 있는 경우에는 마르텐사이트 템퍼링이 발생한다 ${ }^{22)}$. 그 리고 SCHAZ에서의 마르텐사이트 템퍼링은 HAZ에서 경도가 감소하는 현상으로 이어진다. 이를 통해, 780 , $980,1180 \mathrm{MPa}$ 급 강에서 $\mathrm{HAZ}$ 에서 경도가 감소하 는 원인을 확인할 수 있다.

\section{3 탄소 당량식(Carbon equivalent(CE) equ- ation)을 이용한 경도 예측}

서론에서 언급한 바와 같이 본 연구의 목표는 소재의 화학성분을 이용하여 저항 점 용접부의 경도를 예측하 고 파단 모드를 예측하는 것이다. 이를 위해 먼저 소재 의 경도와 강도 간의 상관관계에 대해서 알아보았으며 이는 아래의 식 (1)과 같다.

$$
H V=c \sigma
$$

이때, $\sigma$ 는 소재의 최대 강도이고, $\mathrm{HV}$ 는 소재의 경도 이며, $c$ 는 상수이다. 금속의 경우, $c$ 의 값으로 대부분 $1 / 3$ 을 사용한다 ${ }^{23)}$. 사용한 소재의 모재 경도에 대하여 식 (1)을 이용하여 계산한 값을 Table 4에 나타냈다. Table 4에서 보듯이 소재의 경도를 이용하여 계산한 강도 값이 소재의 실제 강도 값과의 상대오차가 모두 $10 \%$ 이내이므로, 식 (1)을 사용하여 모재 강도를 예 


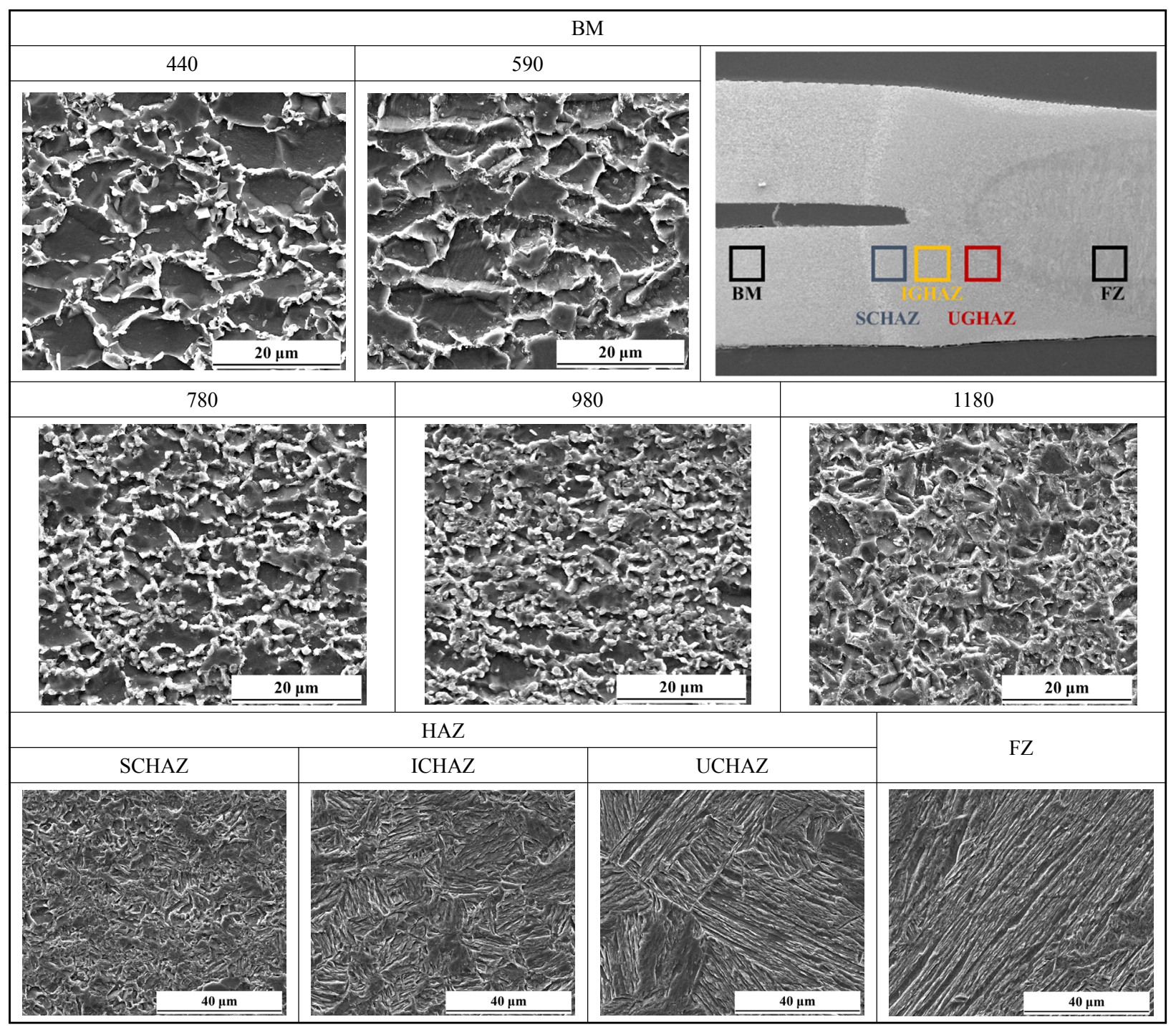

Fig. 6 Microstructure of resistance spot welds

Table 4 Calculated strength using equation (1) and relative error

\begin{tabular}{|c|c|c|c|c|c|}
\hline $\begin{array}{c}\text { Steel grade } \\
\text { (MPa) }\end{array}$ & 440 & 590 & 780 & 980 & 1180 \\
\hline $\begin{array}{c}\text { Calculated } \\
\text { Strength } \\
\text { (MPa) }\end{array}$ & 471.2 & 636.7 & 791.3 & 978.5 & 1185.9 \\
\hline $\begin{array}{c}\text { Relative } \\
\text { error (\%) }\end{array}$ & 7.08 & 7.92 & 1.45 & 0.15 & 0.50 \\
\hline
\end{tabular}

\section{측하였다.}

$\mathrm{FZ}$ 의 경도를 예측하기 위해 탄소 당량(carbon equivalent, $\mathrm{CE}$ )식을 사용하였다. 식 (2)-(8)은 기존에 알려져 있는 여러 가지의 $\mathrm{CE}$ 식을 보여주고 있다. 식 에 들어가는 원소는 식마다 다르며, 원소 앞에 사용되 는 계수 역시 다르다. 모든 식에서 탄소 원소의 계수는 공통적으로 1 이 사용되었다.
$C E Q($ Dearden $)=$

$C+\frac{M n}{6}+\frac{N i}{15}+\frac{C r}{5}+\frac{M o}{4}+\frac{V}{14}+\frac{C u}{13}$

$C E Q(S u z u k u)=$

$C+\frac{M n}{9}+\frac{N i}{40}+\frac{C r}{20}+\frac{M o}{8}+\frac{V}{10}+\frac{C u}{30}$

$\operatorname{Pcm}($ Ito $)=$

$C+\frac{S i}{30}+\frac{M n}{20}+\frac{C u}{20}+\frac{N i}{60}+\frac{C r}{20}$

$+\frac{M o}{15}+\frac{V}{10}+5 B$

$C E($ Yurioka $)=$

$$
\begin{aligned}
& C+A(C)\left\{\begin{array}{l}
5 B+\frac{S i}{24}+\frac{M n}{6}+\frac{C u}{15}+\frac{N i}{15} \\
+\frac{C r+M o+N b+V}{5}
\end{array}\right\} \\
& A(C)=0.75+0.25 \tanh (20(C-0.12))
\end{aligned}
$$




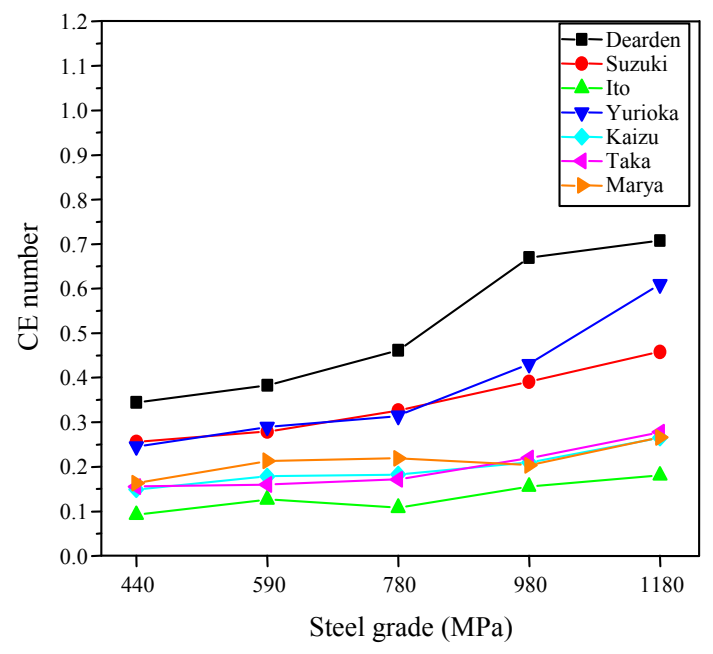

Fig. 7 Carbon equivalent (CE) according to various CE equations of materials with various steel grades

$$
\begin{aligned}
& P L(\text { Kaizu })=C+\frac{S i}{50}+\frac{M n}{25}+\frac{P}{2}+\frac{C r}{25} \\
& P L(\text { Taka })=C+\frac{M n}{22}+14 B \\
& C E(\text { Marya })=C+\frac{S i}{30}+\frac{M n}{20}+2 P+4 S
\end{aligned}
$$

위의 식을 사용하여 $\mathrm{CE}$ 를 계산하였을 때, 소재의 강도 와 $\mathrm{CE}$ 는 Fig. 7과 같이 선형적인 관계를 보였다. 이 렇게 계산한 $\mathrm{CE}$ 를 이용하여 $\mathrm{FZ}$ 의 경도와 $\mathrm{HAZ}$ 의 최 소 경도 예측을 위해 회귀식을 도출하였다. 회귀식과 결정계수는 Table 5 에 나타냈다.

$\mathrm{FZ}$ 와 $\mathrm{HAZ}$ 경도 예측에서 결정 계수가 가장 높은 $\mathrm{CE}$ 식은 각각 $\mathrm{kaizu}$ 와 dearden 식이었다. 그러므로, $\mathrm{FZ}$ 와 $\mathrm{HAZ}$ 의 경도를 예측하기 위해 각각 $\mathrm{kaizu}$ 와 dearden 식을 사용하였으며, 예측한 경도 값과 상대 오차를 Table 6에 나타냈다. FZ의 경우, 상대 오차가 $440 \mathrm{MPa}$ 급 강재에서 가장 낮았으며, 이외의 경우에 도 $1.7 \%$ 이내의 낮은 값을 보이며 예측 값과 실제 측 정한 경도가 유사하였다. $\mathrm{HAZ}$ 의 경우, 상대 오차가 $980 \mathrm{MPa}$ 급 강재에서 $1.82 \%$ 로 가장 낮았으며, $440 \mathrm{MPa}$
Table 5 Regression equation and coefficient of determination $\left(\mathrm{R}^{2}\right)$ for predicting hardness of the $\mathrm{FZ}$ and HAZ using CE

\begin{tabular}{|c|c|c|c|}
\hline $\begin{array}{c}\text { CE } \\
\text { equation }\end{array}$ & \multicolumn{2}{|c|}{ Regression equation } & $\begin{array}{c}\text { Coefficient of } \\
\text { determination } \\
\left(\mathrm{R}^{2}\right)\end{array}$ \\
\hline \multirow{2}{*}{ Dearden } & $\mathrm{FZ}$ & $\mathrm{HV}=75.73 \times \mathrm{CE}+385.09$ & 0.55 \\
\cline { 2 - 4 } & $\mathrm{HAZ}$ & $\mathrm{HV}=359.95 \times \mathrm{CE}+69.54$ & 0.92 \\
\hline \multirow{3}{*}{ Suzuki } & $\mathrm{FZ}$ & $\mathrm{HV}=171.03 \times \mathrm{CE}+365.48$ & 0.70 \\
\cline { 2 - 4 } & $\mathrm{HAZ}$ & $\mathrm{HV}=699.87 \times \mathrm{CE}+14.97$ & 0.87 \\
\hline \multirow{2}{*}{ Ito } & $\mathrm{FZ}$ & $\mathrm{HV}=430.03 \times \mathrm{CE}+367.11$ & 0.82 \\
\cline { 2 - 4 } & $\mathrm{HAZ}$ & $\mathrm{HV}=1522.50 \times \mathrm{CE}+52.97$ & 0.77 \\
\hline \multirow{3}{*}{ Yurioka } & $\mathrm{FZ}$ & $\mathrm{HV}=106.54 \times \mathrm{CE}+383.70$ & 0.85 \\
\cline { 2 - 4 } & $\mathrm{HAZ}$ & $\mathrm{HV}=359.43 \times \mathrm{CE}+118.40$ & 0.72 \\
\hline \multirow{2}{*}{ Kaizu } & $\mathrm{FZ}$ & $\mathrm{HV}=367.37 \times \mathrm{CE}+351.71$ & 0.89 \\
\cline { 2 - 4 } & $\mathrm{HAZ}$ & $\mathrm{HV}=1229.20 \times \mathrm{CE}+12.48$ & 0.74 \\
\hline \multirow{2}{*}{ Taka } & $\mathrm{FZ}$ & $\mathrm{HV}=291.57 \times \mathrm{CE}+366.66$ & 0.79 \\
\cline { 2 - 4 } & $\mathrm{HAZ}$ & $\mathrm{HV}=1009.70 \times \mathrm{CE}+55.82$ & 0.70 \\
\hline \multirow{2}{*}{ Marya } & $\mathrm{FZ}$ & $\mathrm{HV}=418.27 \times \mathrm{CE}+335.04$ & 0.82 \\
\cline { 2 - 4 } & $\mathrm{HAZ}$ & $\mathrm{HV}=1227.80 \times \mathrm{CE}-6.82$ & 0.53 \\
\hline
\end{tabular}

급 강재에서 상대오차가 $13.44 \%$ 로 가장 컸으며 전반 적으로 $\mathrm{FZ}$ 의 경도 예측보다 상대 오차율이 컸다.

\section{4 파단모드 예측}

인장 시험 후의 저항 점 용접부의 파단모드를 예측하 기 위해, 인장 하중이 가해질 때 저항 점용접부에 가해 지는 하중을 계산하였다. Fig. 8(a)에서 보듯이 저항 점용접부의 너깃과 $\mathrm{HAZ}$ 영역을 실린더 형태라고 가정 하였다. 이번 실험에서는 $\mathrm{PF}$ 이 발생할 때, 두 소재 중 에 한 소재에서 용접부가 분리되었으므로, 한 소재의 실린더 영역 절반에 수직 응력이 가해진다고 가정하였 다(Fig. 8(b)). IF가 발생할 때에는 FZ를 가로질러 파단이 발생하므로, 용접부 넓이 영역에 전단 응력이 가해진다고 가정하였다(Fig. 8(c)). $\mathrm{PF}$ 과 $\mathrm{IF}$ 가 발생 할 때의 영역과 응력을 고려하여, 각 파단모드에서의 하중을 식 (9-10)을 이용하여 계산하였고, $P_{P F}$ 와 $P_{I F}$

Table 6 Measured and predicted hardness of FZ and HAZ with relative error

\begin{tabular}{|c|c|c|c|c|c|c|}
\hline \multicolumn{2}{|c|}{ Steel grade (MPa) } & 440 & 590 & 780 & 980 & 1180 \\
\hline \multirow{2}{*}{ Hardness of FZ (HV) } & Measured hardness & 407.4 & 424.2 & 414.2 & 421.9 & 451.9 \\
\cline { 2 - 8 } & Predicted hardness & 406.4 & 417.1 & 418.7 & 428.6 & 448.9 \\
\hline \multicolumn{2}{|c|}{ Relative error (\%) } & 0.25 & 1.68 & 1.08 & 1.58 & 0.66 \\
\hline \multirow{2}{*}{\begin{tabular}{c} 
Hardness of HAZ (HV) \\
\cline { 2 - 8 }
\end{tabular}} & Measured hardness & 170.4 & 217.4 & 254.8 & 316.2 & 311.6 \\
\hline \multicolumn{2}{|c|}{ Relative error (\%) } & 193.3 & 207.1 & 235.5 & 310.4 & 324.1 \\
\hline
\end{tabular}

본 논문은 독자의 이해를 돕기위하여 영문논문을 국문으로 번역하여 게재한 논문입니다. 저자는 본 논문으로 연구업적과 같은 실적에 중복으로 지원받거나 인정받을 수 없음을 알려드립니다. 


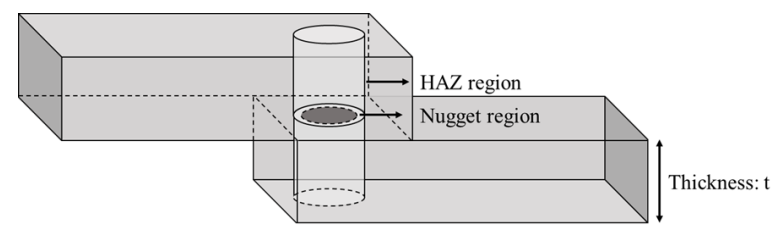

(a)

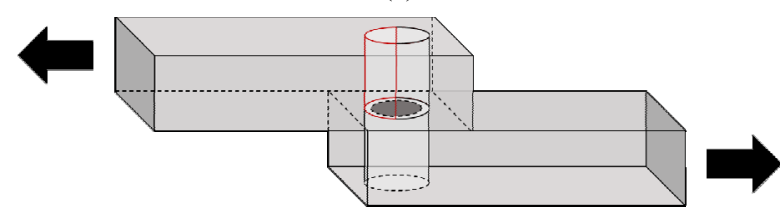

(b)

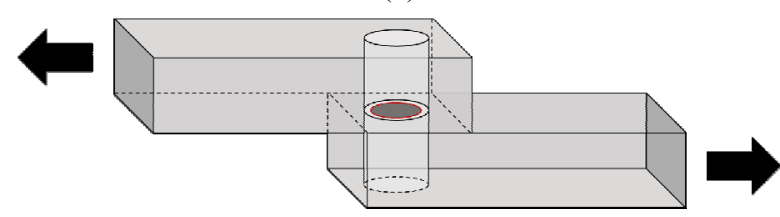

(c)

Fig. 8 Schematic images of (a) resistance spot welds, (b) pull out failure mode and (c) interfacial failure mode with tensile load direction

로 표기하였다.

$$
\begin{aligned}
& P_{P F}=\frac{d}{2} \pi t \sigma_{P F L} \\
& P_{I F}=\frac{d^{2}}{4} \pi \tau_{F Z}
\end{aligned}
$$

이때, $\mathrm{d}$ 은 너깃 지름이고, $\mathrm{t}$ 는 소재의 두께이다. HAZ 연화가 발생한 경우에는 $\mathrm{d}$ 를 너깃 지름이 아닌 HAZ
지름을 사용해야 한다. 모든 소재의 용접부에 대하여, $\mathrm{HAZ}$ 지름을 측정하였을 때, 너깃 지름보다 약 $2 \mathrm{~mm}$ 가 컸으므로, $\mathrm{HAZ}$ 지름은 $\mathrm{d}+2$ 로 가정하였다. $\sigma_{P F L}$ 과 $\tau_{F Z}$ 은 파단 위치에서의 수직 응력과 $\mathrm{FZ}$ 에서의 전단 응 력이다. 응력을 계산하기 위해, 파단 위치에서의 경도 와 $\mathrm{FZ}$ 의 경도와 식 (1)을 이용하였다. 일반적으로 $\mathrm{PF}$ 가 발생할 때의 파단 위치는 모재 또는 $\mathrm{HAZ}$ 영역이 다. 이번 실험에서는 HAZ 연화가 발생한 780, 980 그리고 $1180 \mathrm{MPa}$ 급 강재의 파단 위치를 $\mathrm{HAZ}$ 라고 가정하고, $\mathrm{HAZ}$ 연화가 발생하지 않은 440과 $590 \mathrm{MPa}$ 급 강재의 파단 위치를 $\mathrm{BM}$ 으로 가정하여 $\sigma_{P F L}$ 계산을 위한 경도는 $\mathrm{HAZ}$ 에서의 최소 경도와 $\mathrm{BM}$ 의 경도를 각 각 사용하였다. IF가 발생할 때에는 용융부에 전단 응력 만 발생하므로, $\mathrm{FZ}$ 의 경도를 이용하여 수직 응력을 계 산하고, 식 (11)에 나타낸 von Misses criterion을 사 용하여 수직 응력을 전단 응력으로 바꾸었다.

$$
\sigma=\frac{1}{\sqrt{3}} \tau
$$

식 (9-10)에 모재의 $\sigma$ 와 $\mathrm{FZ}$ 와 HAZ에서의 예측한 경 도를 사용하여, 각각의 전류 값에서의 $P_{P F}$ 와 $P_{I F}$ 를 계 산한 뒤, 두 값을 비교하였다(Table 7). 이때, 이 보 다 큰 경우에는, $\mathrm{PF}$ 가 발생하는 파단 위치에서 파단이 진전하기 위한 구동력이 부족하다고 판단하여 $\mathrm{IF}$ 가 발 생한다고 가정한다(회색). 이와 반대의 경우에는 $\mathrm{PF}$ 가

\begin{tabular}{|c|c|c|c|c|c|c|c|c|c|c|}
\hline $\begin{array}{l}\text { Steel grade } \\
\text { (MPa) }\end{array}$ & \multicolumn{2}{|c|}{440} & \multicolumn{2}{|c|}{590} & \multicolumn{2}{|c|}{780} & \multicolumn{2}{|c|}{980} & \multicolumn{2}{|c|}{1180} \\
\hline $\begin{array}{c}\text { Load }(\mathrm{kN}) \\
\text { Current }\end{array}$ & $P_{1}$ & $P_{I F}$ & $P_{P F}$ & $P_{I F}$ & $P_{P F}$ & $P_{I F}$ & $P_{P F}$ & $P_{I F}$ & $P_{P F}$ & $P_{I F}$ \\
\hline \multirow{2}{*}{$4 \mathrm{kA}$} & 2.72 & 2.29 & 4.21 & 3.93 & 5.30 & 4.46 & 5.71 & 2.33 & 6.07 & 2.61 \\
\hline & & $x$ & \multicolumn{2}{|c|}{$>$} & \multicolumn{2}{|c|}{$>$} & \multicolumn{2}{|c|}{$>$} & \multicolumn{2}{|c|}{$>$} \\
\hline \multirow{2}{*}{$5 \mathrm{kA}$} & 3.58 & 5.90 & 5.13 & 7.49 & 5.70 & 5.95 & 7.71 & 6.61 & 7.49 & 2.50 \\
\hline & & & \multicolumn{2}{|c|}{$<$} & \multicolumn{2}{|c|}{$<$} & \multicolumn{2}{|c|}{$>$} & \multicolumn{2}{|c|}{$>$} \\
\hline \multirow{2}{*}{$6 \mathrm{kA}$} & 4.13 & 9.14 & 5.66 & 10.01 & 7.00 & 11.03 & 8.69 & 9.48 & 8.66 & 8.66 \\
\hline & \multicolumn{2}{|c|}{$<$} & \multicolumn{2}{|c|}{$<$} & \multicolumn{2}{|c|}{$<$} & \multicolumn{2}{|c|}{$<$} & \multicolumn{2}{|c|}{$=$} \\
\hline \multirow{2}{*}{$7 \mathrm{kA}$} & 4.64 & 12.74 & 6.37 & 14.00 & 7.48 & 13.31 & 9.96 & 14.00 & 9.68 & 12.00 \\
\hline & \multicolumn{2}{|c|}{$<$} & \multicolumn{2}{|c|}{$<$} & \multicolumn{2}{|c|}{$<$} & \multicolumn{2}{|c|}{$<$} & \multicolumn{2}{|c|}{$<$} \\
\hline \multirow{2}{*}{$8 \mathrm{kA}$} & 5.19 & 17.34 & 6.43 & 14.37 & 7.96 & 15.80 & 10.74 & 17.21 & 11.36 & 18.70 \\
\hline & \multicolumn{2}{|c|}{$<$} & \multicolumn{2}{|c|}{$<$} & \multicolumn{2}{|c|}{$<$} & \multicolumn{2}{|c|}{$<$} & \multicolumn{2}{|c|}{$<$} \\
\hline \multirow{2}{*}{$9 \mathrm{kA}$} & 5.58 & 21.02 & 7.61 & 22.52 & 8.52 & 18.94 & 11.52 & 20.76 & 11.01 & 17.15 \\
\hline & \multicolumn{2}{|c|}{$<$} & & & & & & & & \\
\hline 101 & 5.51 & 20.35 & 6.93 & 17.58 & 7.85 & 15.20 & 11.86 & 22.41 & 13.09 & 27.14 \\
\hline $10 \mathrm{KA}$ & & & & & & & & & & \\
\hline 11 & 5.60 & 21.25 & 7.91 & 24.97 & 9.88 & 27.91 & 11.91 & 22.65 & 12.74 & 25.27 \\
\hline $11 \mathrm{KA}$ & & & & & & & & & & \\
\hline
\end{tabular}
발생한다고 가정한다(진한 회색). 실제 실험결과인 Table

Table 7 Calculated load of pull-out and interfacial failure mode according to welding currents

본 논문은 독자의 이해를 돕기위하여 영문논문을 국문으로 번역하여 게재한 논문입니다. 저자는 본 논문으로 연구업적과 같은 실적에 중복으로 지원받거나 인정받을 수 없음을 알려드립니다. 
3 의 결과와 비교해 보면, $590 \mathrm{MPa}$ 급 강재의 $5 \mathrm{kA}$, $780 \mathrm{MPa}$ 급 강재의 $5 \mathrm{kA}$ 와 $980 \mathrm{MPa}$ 급 강재의 6 $\mathrm{kA}$ 을 제외한 모든 구간에서 실험 결과와 예측 결과가 일치하였다. $590 \mathrm{MPa}$ 급 강재의 $5 \mathrm{kA}, 780 \mathrm{MPa}$ 급 강재의 $5 \mathrm{kA}$ 와 $980 \mathrm{MPa}$ 급 강재의 $6 \mathrm{kA}$ 에서 $P_{P F}$ 와 $P_{I F}$ 하중의 차이는 각각 $2.36,0.25,0.79 \mathrm{kN}$ 이 다. 각 전류마다 $P_{P F}$ 와 $P_{I F}$ 를 계산할 때, 동일한 경도 를 사용하므로 $P_{P F}$ 와 $P_{I F}$ 를 결정하는데 너깃 지름값이 지배적인 역할을 한다. 이때, 너깃 지름의 경우 측정하 는 과정 중에 오차가 발생할 수 있기 때문에 예측결과 와 실험결과에서 차이가 나는 원인이 될 수 있다. 이러 한 너깃 지름의 측정 오차는 너깃의 단면 가공 시 너깃 의 정중앙을 가공하거나 측정 표본을 늘리는 방법을 통 해 최소화 할 수 있다.

\section{4. 결 론}

본 연구에서는 저강도 강인 $440 \mathrm{MPa}$ 급 강재부터 고강도 강인 $1180 \mathrm{MPa}$ 급 강재까지 저항 점 용접을 수행한 뒤, 기계적 특성을 분석하고 파단모드를 예측하 였다. 기계적 특성을 확인하기 위해, 인장시험을 진행 하고, 너깃 크기와 경도를 측정하였다. 소재의 화학 성 분을 이용하여 FZ와 $\mathrm{HAZ}$ 의 경도를 예측하고, 용접부 에 발생하는 하중을 계산한 뒤, 비교하여 파단모드를 예측하였다.

1) 용접 전류가 증가함에 따라 인장전단강도는 증가 하다가 일정 전류 이상에서 수렴하였다. 너깃 지름도 인장강도와 유사하게 용접 전류가 증가함에 따라 증가 하다가 수렴하였다. 이를 통해, 너깃 지름이 용접부의 강도에 큰 영향을 미친다는 것을 알 수 있다.

2) 경도 측정 결과, $\mathrm{BM}$ 의 경도는 $440,590,780$, 980 그리고 $1180 \mathrm{MPa}$ 급 강재의 순서로 증가하며, $\mathrm{FZ}$ 의 경우에는 $440 \mathrm{MPa}$ 급 강재가 가장 낮고, $1180 \mathrm{MPa}$ 급 강재가 가장 높으며, 590,780 그리고 $980 \mathrm{MPa}$ 급 강재는 유사한 경도 값을 보였다. 또한 780,980 , $1180 \mathrm{MPa}$ 급 강재는 $\mathrm{HAZ}$ 연화가 발생하였다.

3) 다양한 $\mathrm{CE}$ 식을 사용하여 각 소재의 $\mathrm{CE}$ 를 계산 하였다. FZ와 HAZ의 경도 예측을 위해, Kaizu 식과 Dearden 식을 사용하였다. 경도 예측 결과는 실험값 과 유사한 결과를 보였다.

4) 예측한 경도를 사용하여 인장 하중이 가해질 때, 파괴 모드마다 용접부 주변에 발생하는 하중을 계산하였 으며, 계산한 $P_{P F}$ 와 $P_{I F}$ 를 비교하여 파괴 모드를 예 측하였고, 이는 실험 결과와 유사하였다.

\section{감사의 글}

본 연구는 산업통상자원부 및 한국산업기술평가관리 원의 산업핵심기술개발사업의 일환으로 수행되었습니 다. (No.10052779, GIGA급 저비중 경량강재 상온성 형 및 차체 부품화 기술 개발)

ORCID: Heewon Cho: https://orcid.org/0000-0002-9644-6618 ORCID: Sangwoo Nam: https://orcid.org/0000-0002-2486-4941 ORCID: Minjung Kang: https://orcid.org/0000-0003-1894-4301 ORCID: Munjin Kang: https://orcid.org/0000-0003-0598-0848 ORCID: Young-Min Kim: https://orcid.org/0000-0003-3573-8753

\section{References}

1. K. Sugimoto, T. Iida, J. Sakaguchi and T. Kashima, Retained austenite characteristics and tensile properties in a TRIP type bainitic sheet steel, ISIJ Int. 40(9) (2000) 902-908.

https://doi.org/10.2355/isijinternational.40.9021.

2. J. Mortimer, Jaguar uses X350 car to pioneer use of self-piercing rivets, Ind. Robot 28(3) (2001) 192-198. https://doi.org/10.1108/01439910110389344

3. M. Pouranvari, S. M. Mousavizadeh, S. P. H. Marashi, M. Goodarzi and M.Ghorbani, Influence of fusion zone size and failure mode on mechanical performance of dissimilar resistance spot welds of AISI 1008 low carbon steel and DP600 advanced high strength steel, Mater. Design 32(3) (2011) 1390-1398.

https://doi.org/10.1016/j.matdes.2010.09.010

4. M. Jeanneau and P. Pichant, The trends of steel products in the European automotive industry, Metall. Res. Technol. 97(11) (2000) 1399-1408.

https://doi.org/10.1051/metal:2000118

5. B. Smith, A. Spulber, S. Modi and T. Fiorelli, Technology roadmaps: Intelligent mobility technology, materials and manufacturing processes, and light duty vehicle propulsion, Technical Report; Center for Automotive Research, Ann Arbor, MI, USA (2017).

6. R. Schultz and A. Abraham, Metallic material trends for North American light vehicles, Great Designs in steel seminar, May, Livonia, MI, USA (2009).

7. S. Singh and T. Nanda, A Review: Production of Third Generation Advance High Strength Steels, Int. J. Sci. Res. 2(9) (2014) 388-392.

8. I. Hwang, H. Yoon, D. Kim, M. Kang, J. D. Kim and Y. M. Kim, Resistance spot weldability of low density lightweight steel according to electrode shape, J. Weld. Join. 35(2) (2017) 52-57.

https://doi.org/10.5781/JWJ.2017.35.2.8

9. S. G. Choi, I. Hwang, M. Kang, S. Hyun and Y. M. Kim, Optimization of Welding Parameters in Resistance Spot Welding of $980 \mathrm{MPa}$ Grade GA Steel Sheet using Multi-Response Surface Methodology, J. Weld. Join. 
36(4) (2018) 63-69.

https://doi.org/10.5781/JWJ.2018.36.4.7

10. Y. J. Chao, Ultimate strength and failure mechanism of resistance spot weld subjected to tensile, shear, or combined tensile/shear loads, J. Eng. Mater. Technol. 125(2) (2003) 125-132. https://doi.org/10.1115/1.1555648

11. T. B. Hilditch, J.G. Speer and D. K. Matlock, Effect of susceptibility to interfacial fracture on fatigue properties of spot-welded high strength sheet steel, Mater. Design 28(10) (2007) 2566-2576. https://doi.org/10.1016/j.matdes.2006.10.019

12. D. W. Zhao, Y.X. Wang, L. Zhang and P. Zhang, Effects of electrode force on microstructure and mechanical behavior of the resistance spot welded DP600 joint, Mater. Design 50 (2013) 72-77. https://doi.org/10.1016/j.matdes.2013.02.016

13. H. Zhang, A. Wei, X. Qiu and J. Chen, Microstructure and mechanical properties of resistance spot welded dissimilar thickness DP780/DP600 dual-phase steel joints, Mater. Design 54 (2014) 443-449. https://doi.org/10.1016/j.matdes.2013.08.027

14. F. Nikoosohbat, S. Kheirandish, M. Goodarzi, M. Pouranvari and S. P. H. Marashi, Microstructure and failure behaviour of resistance spot welded DP980 dual phase steel, Mater. Sci. Technol. 26(6) (2010) 738-744. https://doi.org/10.1179/174328409X414995

15. M. Goodarzi, S. P. H. Marashi, and M. Pouranvari, Dependence of overload performance on weld attributes for resistance spot welded galvanized low carbon steel, J. Mater. Process. Tech. 209(9) (2009) 4379-4384. https://doi.org/10.1016/j.jmatprotec.2008.11.017

16. H. Lee, N. Kim, and T. S. Lee, Overload failure curve and fatigue behavior of spot-welded specimens, Eng. Fract. Mech. 72(8) (2005) 1203-1221. https://doi.org/10.1016/j.engfracmech.2004.07.013

17. M. Pouranvari, S. P. H. Marashi and D. S. Safanama, Failure mode transition in AHSS resistance spot welds. Part II: Experimental investigation and model validation, Mater. Sci. Eng. A 528(29-30) (2011) 83448352. https://doi.org/10.1016/j.msea.2011.08.016

18. Y. P. Yang, S. Khurana and F. Orth, Development of an Integrated Computational Model to Predict the Performance of AHSS Spot Welds: Methodology and Challenges, Sheet Metal Welding Conference XII, May, Livonia, MI, USA (2015).

19. D. J. Radakovic and M. Tumuluru. Predicting resistance spot weld failure modes in shear tension tests of advanced high-strength automotive steels, Weld. J. 87(4) (2008) 96-s - 105-s.

20. S. G. Choi, I. Hwang, Y. M. Kim, B. Kang and M. Kang, Prediction of the Weld Qualities Using Surface Appearance Image in Resistance Spot Welding, Metals 9(8) (2019) 831-1 - 831-14. https://doi.org/10.3390/met9080831

21. M. Tamizi, M. Pouranvari, and M. Movahedi. Welding metallurgy of martensitic advanced high strength steels during resistance spot welding, Sci. Techno. Weld. Join. 22(4) (2017) 327-335.

https://doi.org/10.1080/13621718.2016.1240979

22. M. I. Khan, M. L. Kuntz, E. Biro and Y. Zhou, Microstructure and mechanical properties of resistance spot welded advanced high strength steels, Mater. Trans. 49(7) (2008) 1629-1637. https://doi.org/10.2320/matertrans.MRA2008031

23. P. Zhang, S.X. Li and Z.F. Zhang, General relationship between strength and hardness, Mater. Sci. Eng. A 529(25) (2011) 62-73.

https://doi.org/10.1016/j.msea.2011.08.061 